\title{
Kavram Karikatürü Destekli Fen Öğretimi Hakkında Öğretmen Adaylarının Görüşleri ${ }^{1}$
}

\section{Emine YURTYAPAN ${ }^{2}$ Nezahat KANDEMIR ${ }^{3} \quad$ Şevket KANDEMIR $^{4}$}

\section{$\ddot{\mathbf{O} z}$}

Bu çalışmanın amacı, kavram karikatürü destekli fen öğretimi laboratuvar uygulamaları alan fen bilgisi öğretmen adaylarının görüşlerini belirlemektir. Çalışma nitel araştırma yöntemlerinden olgu bilim yöntemi ile yürütülmüştür. Çalışmanın örneklemini Fen Bilgisi Öğretmenliği üçüncü sınıfta öğrenim gören öğretmen adayları (n=6) oluşturmaktadır. Örneklem seçiminde amaçlı örnekleme yöntemlerinden ölçüt örnekleme yöntemi kullanılmıştır. Bu çalışma kapsamında fen öğretimi laboratuvar uygulamaları dersi TGA öğretim yöntemi ile yürütülmüş olup, dersin tahmin aşamasında kavram karikatürü destekli etkinliklere yer verilmiştir. Veriler yarı yapılandırılmış mülakatlar yoluyla elde edilmiştir. Mülakatların analizinde NVIVO 9.0 programı kullanılmıştır. Araştırmanın sonucunda elde edilen veriler incelendiğinde kavram karikatürü destekli fen öğretimi hakkında öğretmen adayları ders öncesinde kaygılarının olduğu bildirmişlerdir. Ancak bu kaygılarının dersten sonra azaldığını, ileride meslek hayatlarında bu derste edindikleri tecrübeler ile kavram karikatürlerini kendi öğrencilerinde kullanacaklarını ifade etmişlerdir. Ayrıca kendilerinde derse yönelik motivasyon durumlarının artmasıyla bilişsel ve duyuşsal becerilerin gelişmesini sağladığını, özellikle psikomotor becerilerinin geliştiğini belirtmişlerdir.

Anahtar Kelimeler: Fen Öğretimi, kavram karikatürü, fen bilgisi öğretmen adayları.

\footnotetext{
${ }^{1}$ Bu çalışma 2016 yılında düzenlenen 25. Ulusal Eğitim Bilimleri Kongresinde sunulmuştur

${ }^{2}$ Yüksek Lisans Öğrencisi, Amasya Üniversitesi, Fen Bilimleri Enstitüsü, emineyurtyapan@ hotmail.com

${ }^{3}$ Doç. Dr., Amasya Üniversitesi, Eğitim Fakültesi, Matematik ve Fen Bilgisi Eğitimi Bölümü, nezahat.kandemir@amasya.edu.tr

${ }^{4}$ Prof. Dr., Amasya Üniversitesi, Eğitim Fakültesi, Matematik ve Fen Bilgisi Eğitimi Bölümü, sevket.kandemir@amasya.edu.tr
} 
The Views of The Prospective Teachers About Science Teaching

\title{
With Concept Cartoons Support
}

\begin{abstract}
The aim of this study is to determine the views of the science prospective teachers who get science education with concept cartoons support. The study was carried out using phenomenological method which is one of the quantitative methods. The sample of the study contained science prospective teachers $(n=6)$ attending to the third grade of Science department. For the sample selection, scale sampling method was used. In this context science teaching laboratory applications were carried out by using POE (PredictionObservation-Explanation) teaching method and the activities supported by concept cartoons were placed in the prediction step. The data was obtained through semi-structured interview questions. NVIVO 9.0 program was used for the analysis of the interviews. When the data was evaluated, the prospective teachers claimed that they were anxious about science teaching supported by cartoon before the class. However, it was seen that that their anxiety became less after the class and they added that they would use the same method in their classes when they start to their career. Moreover, by increasing their motivation, their cognitive and affective skills were improved and especially their psycho-motor skills were improved as well.
\end{abstract}

Keywords: Science teaching, concept cartoons, science prospective teachers. 


\section{Giriş}

Batılı ülkelerde Fen Bilimleri eğitiminde başlayan yenileşme hareketi 1960'larda Türk Milli Eğitimini etkileyerek öğrenci merkezli uygulamaların ve laboratuvar çalışmalarının ülkemizdeki fen eğitimine girmesini sağlamıştır. Fen Bilimleri deneye, gözleme, keşfe, araştırmaya, sorgulamaya ve tartışmaya dayanan bir bilim olması nedeniyle laboratuvar yöntemi fen eğitiminin ayrılmaz bir parçasıdır. Fen eğitiminde laboratuvar uygulamaları ile ilgili yapılan pek çok çalışmada laboratuvar uygulamalarının fen öğretimi için gerekli olduğu ancak bu uygulamaların yeterli, etkin ve doğru yapılamadığı tespit edilmiştir (Böyük, Demir ve Erol, 2010; Demir, Böyük ve Koç, 2011; Ekici, 1996; Erten, 1991; Güneş, Şener, GermiTopal ve Can, 2013). Bu uygulamaların doğru, etkin ve yeterli bir şeklide yapılamamasının ortama bağlı pek çok sebebi (okul ve laboratuvar fiziki şartlarının yetersizliği, malzeme, araç ve gereç eksiliği, sınıf mevcutlarının kalabalık oluşu vb.) olmakla birlikte, öğretmenlerin yeterli düzeyde laboratuvar uygulamaları bilgi ve becerisine sahip olmamasına da bağlıdır (Güneş, Güneş ve Hoplan, 2012). Öğretmenlerin yeterli bilgi ve beceri düzeyine sahip olmaması, eğitim fakültelerinde okuyan fen bilgisi öğretmen adaylarının fen öğretimi laboratuvar uygulamalarına dikkati çekmektedir. Dolayısıyla bu çalışmada Fen Bilgisi Öğretmenliği üçüncü sınıf öğretmen adaylarına örnek bir uygulama olması açısından fen öğretimi laboratuvarı dersi Tahmin-Gözlem-Açıklama (TGA) öğretim yöntemi ile yürütülmüş olup bu öğretim yöntemi içerisinde kavram karikatürü destekli etkinliklere yer verilmiştir.

Son yıllarda laboratuvar derslerinde TGA yöntemi kavram yanılgılarının belirlenmesinde (Bilen ve Köse, 2012; Mısır ve Saka, 2012; Yavuz ve Çelik, 2013) ve kavram öğretiminde sıkça kullanılan etkili bir öğretim yöntemidir (Liew, 1995, akt. Köse, Coştu ve Keser, 2003). Bu öğretim yönteminde konu ile ilgili tahminde bulunma bu tahminlerin paylaşılması, gözlem yapma, gözlemlerle tahminler arasında ilişki kurma, gözlemler ve tahminler arasında çelişkiler varsa bu çelişkilerin giderilmesi aşamaları bulunur (White ve Gunstone, 1992, akt. Özyllmaz-Akamca ve Hamurcu, 2009). Genellikle bu yöntemin uygulanmasında tahmin aşamasında açık uçlu sorular kullanılır, gözlem aşamasında deneyler yapılır, açıklama ise öğretmen tarafından anlatım ile geçekleştirilir. Dolayısıyla bu öğretim yöntemi pek çok etkinliğin bir arada kullanılmasına imkân veren bir öğretim yöntemidir. TGA öğretim yönteminde birbirinden farklı etkinliklerin kullanılması öğretmen adaylarının farklı öğrenme şekillerine hitap etmesi açısından önemli bir yöntem olduğunu göstermektedir. Bu çalı̧̧mada TGA öğretim yönteminin genel kullanım şekli dışında tahmin 
aşamasında açık uçlu sorularla birlikte kavram karikatürleri, gözlem aşamasında öğretmen adayları tarafından yapılan bireysel ya da grup deneyleri ve açıklama aşamasında ise anlatım yöntemi kullanılmıştır. Böylece bu çalışma ile öğretmen adaylarının TGA öğretim yöntemi içerisinde pek çok öğretim yönteminin ve öğrenme etkinliklerinin uygulanma şekillerini görmeleri sağlanmıştır.

Kavram karikatürleri herhangi bir senaryo durumu üzerinde birden fazla karakterin düşüncelerini içeren karikatürlerdir. Kavram karikatürlerinin diğer karikatür çeşitlerinden farkı mizah amacının olmamasıdır. Bu karikatürler öğrencilerin düşünmesini, sorgulamasını, eleştirmesini ve tartışmasını sağlayarak her hangi bir konu hakkındaki ön düşüncelerin ortaya konulmasına yardımcı olur. Bu nedenle kavram karikatürleri öğrencilerin ön bilgilerinde yer alan kavram yanılgılarının belirlenmesine ve bu yanılgıları tartışma ortamı sağlayarak giderilmesine katkıda bulunur (Yıldız, 2008). Ayrıca kavram karikatürlerinde görsel ve sözel öğelerin bir arada bulunması soyut fen kavramların somutlaştırılarak daha kolay ve anlamlı öğrenilmesini sağlar (Kirişcioğlu ve Başdaş, 2007, akt. Şaşmaz-Ören, 2009). Yapılan araştırmaların çoğunda kavram karikatürlerinin kavram yanılgılarının belirlenmesi, giderilmesi ve kavram öğretimi üzerinde olumlu etkileri olduğu görülmektedir (Çiğdemtekin, 2007; Demir, Uzoğlu ve Büyükkasap, 2012; Ekici, Ekici ve Aydın, 2007; Erdoğan ve Özsevgeç, 2012; Eroğlu, 2010; Gül, Köse ve Konu, 2014; Meriç, 2014; Minárechová, 2016; Oluk ve Özalp, 2007; Özyılmaz-Akamca, Ellez ve Hamurcu, 2009; Taşlıdere, 2013; Yıldız, 2008). Ayrıca kavram karikatürlerinin sorgulayıcı öğrenme, akademik başarı, tutum, mantıksal düşünme, motivasyon, kaygı gibi duyuşsal ve bilişsel özellikler üzerindeki etkilerine yönelik çalışmalarda bulunmaktadır (Balım, İnel ve Evrekli, 2008; Balım, İnelEkici ve Özcan, 2016; Baysarı, 2007; İnel ve Balım, 2011; Köklükaya, Güven-Yıldırım ve Selvi, 2016; Özmen, Demircioğlu, Burhan, Naseriazar ve Demircioğlu, 2012; Şengül ve Üner, 2010; Topkaya, 2016).

Alan yazını incelendiğinde fen öğretiminde kavram karikatürü kullanılması ile ilgili görüşlerin belirlenmesine yönelik nitel çalışmaların sınırlı olduğu görülmektedir (Aydın, 2015; Balım, Ormanc1 ve diğ., 2016; Birişçi, Metin ve Karakaş, 2010; Cengizhan, 2011; Duban, 2013; İnel, Balım ve Evrekli, 2009; Soylu, 2011, akt. Balım, Ormancı ve diğ., 2016; Şaşmaz-Ören ve Meriç, 2014). Bu çalışmalara bakıldığında İnel ve diğerleri (2009), Soylu (2011), Şaşmaz-Ören ve Meriç (2014), Aydın (2015) çalışmalarında kavram karikatürü hakkında ilköğretim öğrencilerinin görüşlerine, Duban (2013) öğretmenlerin, Balım, Ormancı ve diğerleri (2016) ise hem öğrenci hem de öğretmen görüşlerine başvurdukları görülmektedir. Birişçi ve diğerleri (2010) ile Cengizhan (2011) tarafından yapılan 
çalışmalarda ise kavram karikatürlerine ilişkin öğretmen adaylarının görüşleri alınmıştır. Kavram karikatürü ile ilgili öğretmen adayları ile gerçekleştirilen bu çalışmaların konularına bakıldığında fen öğretimine ilişkin herhangi bir çalışmanın olmadığı görülmüştür. Belirtilen sebeplerden dolayı bu çalışmanın yapılmasına gerek duyulmuştur ve çalışmada kavram karikatürü destekli fen öğretimi laboratuvar uygulamaları hakkında fen bilgisi öğretmen adaylarının görüşlerinin alınması amaçlanmıştır.

\section{Problem}

Kavram karikatürü destekli fen öğretimi laboratuvar uygulamaları dersi hakkında fen bilgisi öğretmen adaylarının görüşleri nelerdir?

\section{Alt Problemler}

Çalışmanın amacı doğrultusunda araştırmanın alt problemleri fen bilgisi öğretmen adaylarının;

Kavram karikatürü destekli yürütülen fen öğretimi laboratuvar uygulamaları dersi hakkındaki genel düşünceleri nelerdir?

> Kavram karikatürü destekli fen öğretimi laboratuvar uygulamaları dersinin kendi öğrenmeleri üzerindeki düşünceleri nelerdir?

Kavram karikatürü destekli fen öğretimi laboratuvar uygulamaları dersinin etkili olabilmesi konusundaki düşünceleri nelerdir?

\section{Yöntem}

\section{Araştırmanın Modeli}

Kavram karikatürü destekli fen öğretimi laboratuvar uygulamaları hakkında fen bilgisi öğretmen adaylarının görüşlerini incelemek amacıyla gerçekleştirilen bu çalışma nitel araştırma yöntemlerinden, olgu bilim yöntemi ile yürütülmüştür. Olgu bilim yönteminin temelinde gerçeklere ulaşmaktan ziyade bireylerin yaşadıkları deneyimi, kendi gerçekliklerinde nasıl anlamlandırdıklarına ulaşmak vardır (Bakanay ve Çakır, 2016). Her birey yaşadıkları bir deneyimi farklı şekillerde anlatabilir. Olgu bilim çalışmalarında bir olgu üzerindeki farklı insanların deneyimleri parantez içerisine alınır, analiz edilir ve karşılaştırılır (Patton, 2014). Bu sayede araştırmacı, bireylerin farklı ifadelerinden yola çıkarak aynı durumu farklı bakış açılarından değerlendirip, daha detaylı bir şekilde inceleyebilir. Van Der Mescht (2004) olgu bilim yönteminin kullanıldığı eğitim çalışmalarının, öğrenme ve öğretme 
ile ilgili deneyimlerin araştırılmasına ve araştırmayı yapan kişiye bu deneyimleri farklı bir bakış açısı ile incelemesine imkân veren bir yöntem olduğunu belirtmektedir. Olgu bilim yöntemi belirli bir durum hakkında kesin ve genel sonuçlar ortaya koymaktan daha çok o durumu ayrıntılı bir şekilde anlamamızı sağlayacak örnekler, açıklamalar, yaşantılar ve sonuçlar elde edilmesini sağlayabilir (Yıldırım ve Şimşek, 2016). Sonuç olarak bu araştırmada öğretmen adaylarının bu derste yaşadıkları deneyimler hakkındaki görüşlerinin, düşüncelerinin alınması ve her bir öğretmen adayının kavram karikatürü destekli fen öğretimi laboratuvarı uygulamaları dersine olan farklı bakış açılarının ayrıntılı bir şekilde değerlendirilmesi amaçlandığı için çalışma olgu bilim yöntemi ile yürütülmüştür.

\section{Örneklem}

Araştırmanın örneklemini Fen Bilgisi Öğretmenliği üçüncü sınıf öğretmen adayları (n=6) oluşturmaktadır. Bu çalışmada örneklem, amaçlı örnekleme yöntemlerinden ölçüt örnekleme yöntemi ile seçilmiştir. Amaçlı örnekleme nitel araştırmalarda bir fenomenin derinlemesine araştırılabilmesine ve küçük bir örneklem oluşturulmasına imkân verir (Patton, 2014). Yıldırım ve Şimşek'e (2016) göre olgu bilim araştırmalarında birden fazla uzun ve ayrıntılı görüşmeler yapıldığı için örnekleme dahil edilecek kişi sayısı 10'u geçmemelidir. Bu nedenle çalışmadaki örneklem sayısı altı öğretmen adayı ile sınırlandırılmıştır. Araştırmanın örneklemi olan altı kişi belirlenirken çalışmanın amacı doğrultusunda çeşitli ölçütler dikkate alınmıştır. Çünkü olgu bilim çalışmalarında örneklem belirlenirken araştırmanın odaklandığ 1 durumu yaşayan ve bu durumu yansitabilecek bireyler ya da gruplar seçilmelidir (Büyüköztürk, Kılıç-Çakmak, Akgün, Karadeniz ve Demirel, 2016). Dolayısıyla bu çalışmada örneklemin belirlenmesindeki temel ölçüt kavram karikatürü destekli fen öğretimi laboratuvar uygulamaları dersi alan fen bilgisi öğretmen adaylarıyla gerçekleştirilmesidir. Öğretmen adayları üç grup halinde bu dersi almışlardır. Fen öğretimi laboratuvar uygulamaları dersini veren öğretim üyesinden alınan öğretmen adaylarının kişisel özellikleri, iletişim becerileri ve bilgilerine göre her gruptan gönüllülük esasına dayanarak ikişer öğrenci seçilerek 25-30 dakikalık mülakatlar yapılmıştır. Yıldırım ve Şimşek'e (2016) göre ölçüt örnekleme yöntemi önceden belirlenmiş ölçütleri karşılayan bütün durumların çalışılmasına imkân veren bir örneklem belirleme yöntemidir. $\mathrm{Bu}$ nedenle çalışmada örneklem belirlenirken amaçlı örneklem yöntemlerinden ölçüt örneklem yöntemi kullanılmıştır. Öğrencilerin demografik özellikleri Tablo 1'de gösterilmiştir. 
Ege Eğitim Dergisi 2017 (18) 2: 738-773

Kavram Karikatürü Destekli Fen Öğretimi Hakkında Öğretmen Adaylarının Görüşleri

Tablo 1. Öğrencilerin demografik özellikleri

\begin{tabular}{ccccccc}
\hline Öğrenciye verilen kod & Ö1 & Ö2 & Ö3 & Ö4 & Ö5 & Ö6 \\
\hline Sinıf seviyesi & 3 & 3 & 3 & 3 & 3 & 3 \\
Cinsiyeti & $\mathrm{E}$ & $\mathrm{K}$ & $\mathrm{K}$ & $\mathrm{K}$ & $\mathrm{K}$ & $\mathrm{K}$ \\
\hline
\end{tabular}

\section{Uygulama Süreci}

Kavram karikatürü destekli fen öğretimi laboratuvarı dersinin uygulama süreci başlamadan bir hafta önce araştırmacı tarafından öğretmen adaylarına araştırmanın amacı hakkında ve uygulanacak kavram karikatürü destekli öğretim hakkında bilgi verilmiştir. Kavram karikatürü destekli etkinlikler biyoloji konularına yöneliktir. Bu konular Tablo 2'de belirtilmiştir. Bu derste öğretim TGA öğretim yöntemi ile gerçekleştirilmiş olup geliştirilen kavram karikatürleri tahmin aşamasında kullanılmıştır. Kavram karikatürleri öğretmen adaylarına çalışma yaprakları şeklinde dağıtılmıştır. Dağıtılan çalışma yaprakları Ek 1'de verilmiştir. Gözlem aşamasında öğretmen adayları ile grup ya da bireysel deneyler gerçekleştirilmiştir. Açıklama aşamasında ise araştırmacı tarafından konu ile ilgili açıklamalar yapılarak ders sonlandırılmıştır. Araştırmada her bir grup 4 hafta olmak üzere toplam on iki haftada tamamlanmıştır.

Tablo 2. Kavram karikatürü geliştirilen biyoloji konuları

\begin{tabular}{ccccc}
\hline & 1. Hafta & 2. Hafta & 3. Hafta & 4. Hafta \\
\cline { 2 - 5 } & Göz & Asit Yağmurları & $\begin{array}{c}\text { Fotosentez } \\
\text { Kan Grubu } \\
\text { Tayini }\end{array}$ & $\begin{array}{c}\text { Hücre Zarından } \\
\text { Madde Geçişi } \\
\text { Hücresel Solunum }\end{array}$ \\
Bulak & Sera Etkisi & $\begin{array}{c}\text { Kan Basınc1 } \\
\text { Çimlenme }\end{array}$ & \\
& Deri & Doşaltım Sistemi & & \\
& Dil & & & \\
\hline
\end{tabular}

\section{Veri Toplama Araçları}

Çalışmadaki veriler uygulanan kavram karikatürü destekli eğitime yönelik yapılan yarı yapılandırılmış mülakatlar yolu ile elde edilmiştir. Mülakatın temel amacı bir hipotezi test etmek değil, insanların deneyimlerini ve bu deneyimlerini nasıl anlamlandırdıklarını anlamaya çalışmaktır (Türnüklü, 2000). Yarı yapılandırılmış mülakatlarda önceden hazırlanan soruları içeren bir görüşme protokolü olmakla birlikte bu mülakatlar araştırmacıya karşısındaki kişiden gelen cevaplara bağlı olarak alt sorular sorma imkânı verir. Bu nedenle yarı yapılandırılmış mülakatlar ayrıntılı bilgi elde edilmesinde yardımcı olduğu için eğitim araştırmalarında daha uygun bir araştırma tekniğidir (Türnüklü, 2000). Araştırmacı tarafından 
hazırlanan mülakat, dokuz sorudan oluşmaktadır. Yarı yapılandırılmış mülakat formu Ek 2' de verilmiştir. Sorular kavram karikatürü destekli fen öğretimi laboratuvar uygulamaları dersinin öğretim süreci hakkındaki algı, düşünce ve yorumlarının alınması amacına yönelik olarak hazırlanmıştır. Kapsam geçerliliğinin sağlanması için uzman görüşüne başvurulmuştur. Mülakat soruları çalışma grubuna uygulanmadan önce çalışma grubunun dışından iki öğretmen adayına uygulanarak pilot çalışması yapılmıştır. Mülakatlar öğretmen adayları ile bireysel olarak yapılmış olup öğretmen adaylarının izniyle ses kayıtları alınmıştır.

\section{Verilerin Analizi}

İçerik analizi yöntemi genellikle gözleme dayalı alınan notlardan çok metinlerin (mülakat dökümleri, günlükler ve dokümanlar) analizinde kullanılır (Patton, 2014). Ayrıca içerik analizi bir araştırmada elde verilerin temelindeki kavramları derinlemesine incelenmesini ve bu kavramlar arasındaki ilişkileri ortaya çıkmasını sağlar (Miles, Huberman ve Saldana, 2014). Bu nedenle çalışmamızda yarı yapılandırılmış mülakatlar yolu ile elde edilen verilerin analizinde içerik analizi yöntemi kullanılmıştır. İçerik analizi yöntemi belirli bir işlem sırası ile uygulanması gerekir (Kishore, Agrawal ve Rao, 2005, akt. Meşeci, Karamustafaoğlu ve Bacanak, 2012). İlk olarak öğretmen adaylarının izni çerçevesinde bireysel görüşmeler yapılmıştır ve görüşmeler sesli kayıt altına alınmıştır. Ses kayıtları öğretmen adaylarının ifadelerine bire bir uygun olacak şekilde bilgisayar ortamında yazılmıştır. Sonra yazılı metinler NVIVO 9.0 bilgisayar programına aktarılmıştır. Bu nitel veri analiz programı ile öğretmen adaylarının aynı sorulara verdikleri cevaplar karşılaştırılarak kodlanmıştır. NVIVO 9.0 nitel veri analiz programı ile oluşturulan kodlamalar, temalar ve alt temalar haline getirilerek model ve grafikler halinde sunulmuştur.

\section{Bulgular}

Araştırmanın alt problemleri doğrultusunda elde edilen bulgular üç başlık altında verilmiştir.

\section{Birinci Alt Probleme İlişkin Bulgular}

Araştırmanın birinci alt problemine göre öğretmen adaylarının kavram karikatürü destekli fen öğretimi dersi hakkındaki genel düşünceleri alınmıştır. Öğretmen adayları bu alt problem doğrultusunda yöneltilen sorulara fen öğretimi laboratuvarı dersinde öğretimin kavram karikatürü destekli olacağını öğrendiğinde ilk düşüncelerini ve öğretim yapıldıktan sonra ders hakkındaki şimdiki düşüncelerini söyleyerek cevaplamışlardır. Dolayısıyla öğretmen adaylarının genel düşüncelerine ait bulgular öğretmen adaylarının ilk düşünceleri ve şimdiki 
düşünceleri şeklinde ayrı ayrı incelenmiştir. Öğretmen adaylarının kavram karikatürü destekli fen öğretimi laboratuvarı uygulamaları dersi hakkındaki genel görüşlerine ait kodlamalardan oluşan model Şekil 1'de verilmiştir. Şekil 1 incelendiğinde, çalışma grubundaki öğretmen adaylarının uygulama öncesinde ve sonrasında ders hakkında olumlu ve olumsuz düşüncelere sahip oldukları görülmektedir. Ayrıca uygulama sonrasında belirttikleri olumlu ve olumsuz görüşlerin uygulama öncesinde belirttikleri düşüncelerden hem sayıca daha fazla hem de daha ayrıntılı olduğu belirlenmiştir. Özellikle olumlu düşüncelerdeki artışın daha fazla olduğu görülmektedir.

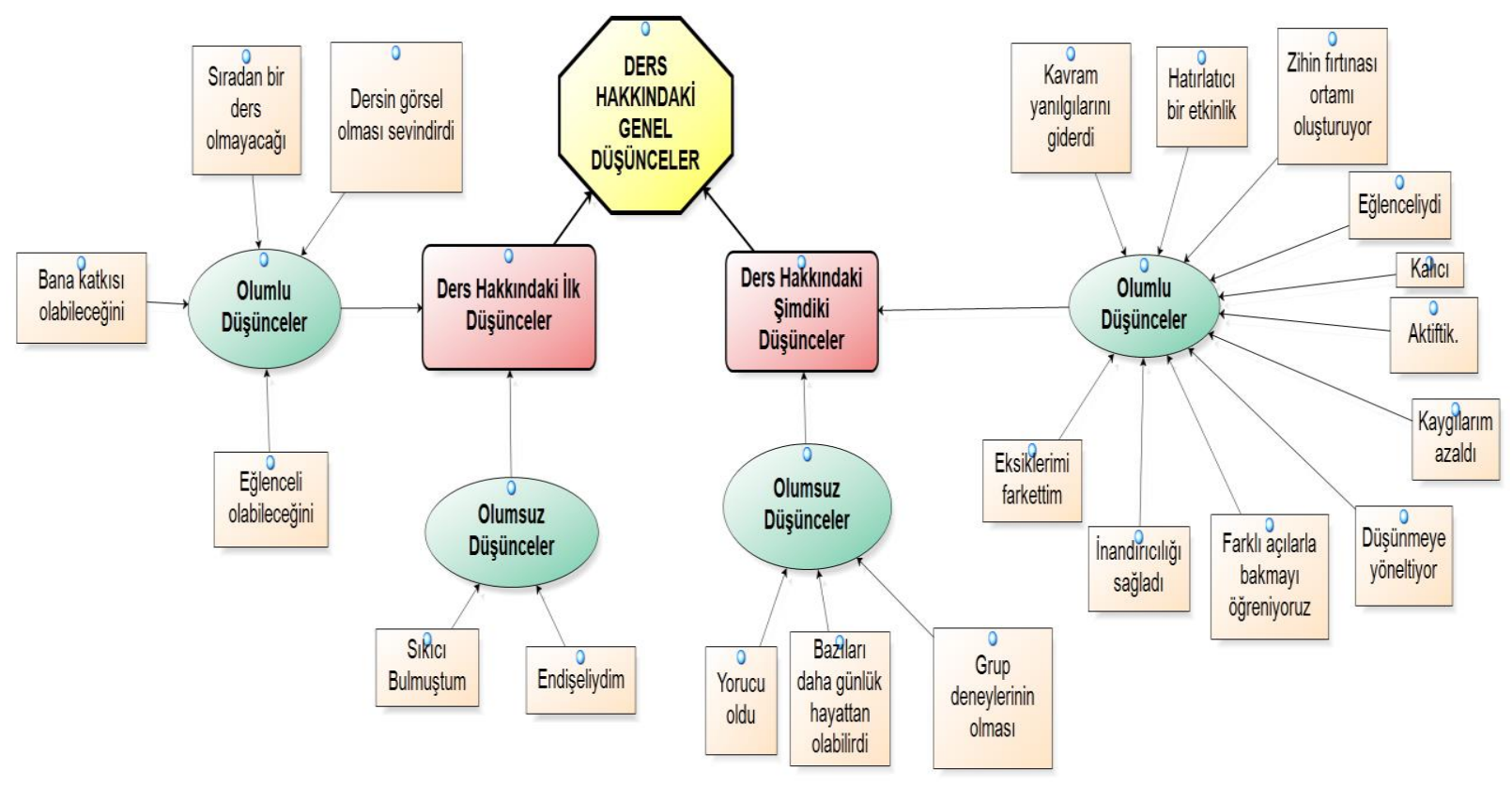

Şekil 1. Kavram karikatürü destekli fen öğretimi laboratuvarı dersi hakkındaki genel görüşler

Öğretmen adaylarının kavram karikatürü destekli olarak yürütülecek olan ders hakkındaki ilk düşüncelerin sayısını gösteren grafik ise Grafik 1'de, şimdiki düşüncelerinin sayısını gösteren grafik ise Grafik 2'de gösterilmiştir. Grafik 1 ve Grafik 2 incelendiğinde olumlu düşünce olarak en fazla öğretmen adaylarının derste daha aktif olduklarını, farklı açılardan bakmayı öğrendiklerini, kalıcı olduğunu ve ders ile ilgili kaygılarının azaldığını belirttikleri görülmektedir. Olumsuz düşüncelere baktığımızda ise bu düşüncelerin çeşitlendiğini ancak öğretmen adaylarının verdiği olumsuz cevap oranlarının eşit olduğu bulunmuştur. İlk düşünceler ve şimdiki düşünceleri karşılaştırdığımızda ders hakkındaki ilk düşüncelerinde endişeli olduğunu belirten öğretmen adaylarının ikisinin (Ö4 ve Ö5) öğretim yapıldıktan sonra kaygılarının azaldığını söylediklerini, ilk düşüncelerinde endişeliydim 
yanıtı veren Ö3 öğretmen adayının ise öğretimden sonra ders hakkındaki düşüncelerinin olumlu yönde değiştiğini görmekteyiz. Konuyla ilgili bu öğrencilerin cevapları şöyledir:

Ö3: “.......Acaba daha önceden hani görmediğim veya da duymadĭ̆ım bir şeyler hakkında tahmin yürütebileceğim mi ya da ögrenebilecĕgim mi ya da faydası ne olur gibi bir şeyler düşündüm ...... Bence güzel oldu dediğim gibi hani kendi bilgilerimi yanlış bildiklerimi geri dönüt sağlandl, bir nevi. Hani yanlış bilsem de ögrenmiş oldum ben onu. Yani zaten ben onu isterim. Hani bir şeyi bazen bazı hocalar anlatır geçer. Sen bilsen de bilgilerin en azında ben yazdım oraya bir şeyler hani kesin kalıcı bir şey oldu. Sonra siz anlattınız kararlar değişti. "Hımm, böyleymiş.” diye düşündüm. Yani , “Yanlış biliyormuşum.” Deyip, bir de hani kendimiz yaptık. Kendimiz yaptı̆̆ımız için iyice uyarladı yani insan yaparak öğrenir ya her şeyi. O yüzden daha kalıcı oldu..... Ali'yi tutuyor veya da Veli'yi tutuyor. Bir de neden tuttuğunu da açıklattırıyorsunuz, siz. Hani, olaya farklı açılarla bakmayı öğreniyoruz. “Hımm, şu açılarla da bakılabilir." diyoruz...."

Ö4: "Illk düşüncem bir an önce hani bir panik oldu zaten. Ne biliyoruz, bilmiyoruz? Acaba doğru söyler miyiz? Yanlış söyler miyiz? Hani gibi bir ön yargımız oldu amma ilerleyen zamanlarda pekişsi. Hani ne yapmaya çalıştı̆̆ınız daha da açıklaştı, daha da yalın bir hale geldi....Sonraki basamaklarda ilk önce endişeli filan okuyorsun ama sonradan hani artık yapabileceğine inanıyorsun. O düşüncelerin pekişiyor ya da daha önce öğrendiğin bilgilerden yola çıkarak düşünceler hani yansıtabiliyorsun oraya. Diğer balonları filan dolduruyorsun. Ön yargı bir anda ortadan kallyor gibi oluyor. Bir de konuyu biliyorsan zaten tamamen devam ediyor, iyi oluyor."

Ö5: "İşte başta şekilli şeyler hani karikatür deyince bir tebessüm ettiriyor. Ondan sonra bu şekilde hiç işlemediğim için nasıl olacak endişesi de vardı.Siz anlattıktan sonra hani gördük zaten şey olarak, görsel olarak da yani etkili olduğunu düşünüyorum......O deneyleri yaptıktan sonra, o karikatür şeyini doldurduktan sonra bu endişem kesinlikle gitti..........Şu an için iyi olduğunu düşünüyorum. Çünkü herkes için hani yani bizim daha önceki konumuzda $5 E$ modeliydi. Herkese konu veriliyor. Ben mesela anlattığım konu destek ve hareket sistemini anlattım. Anlattı̆̆ım konuyu biliyorum. Diğer şeylerde dă̆llma oluyor. Dikkat dă̆ınıklı̆̆l oluyor. O yüzden çok etkili olduğunu düşünmüyorum ama şimdi hoca bütün herkese seslendiği için ve herkesin bireysel olarak ve karikatürü olduğu için yani istediği yorumu da yapabileceği bir kutucuğu var ve ya katılabileceği özgür şeyler var. İşte seçenekler var. O yüzden yani iyi, olumlu." 


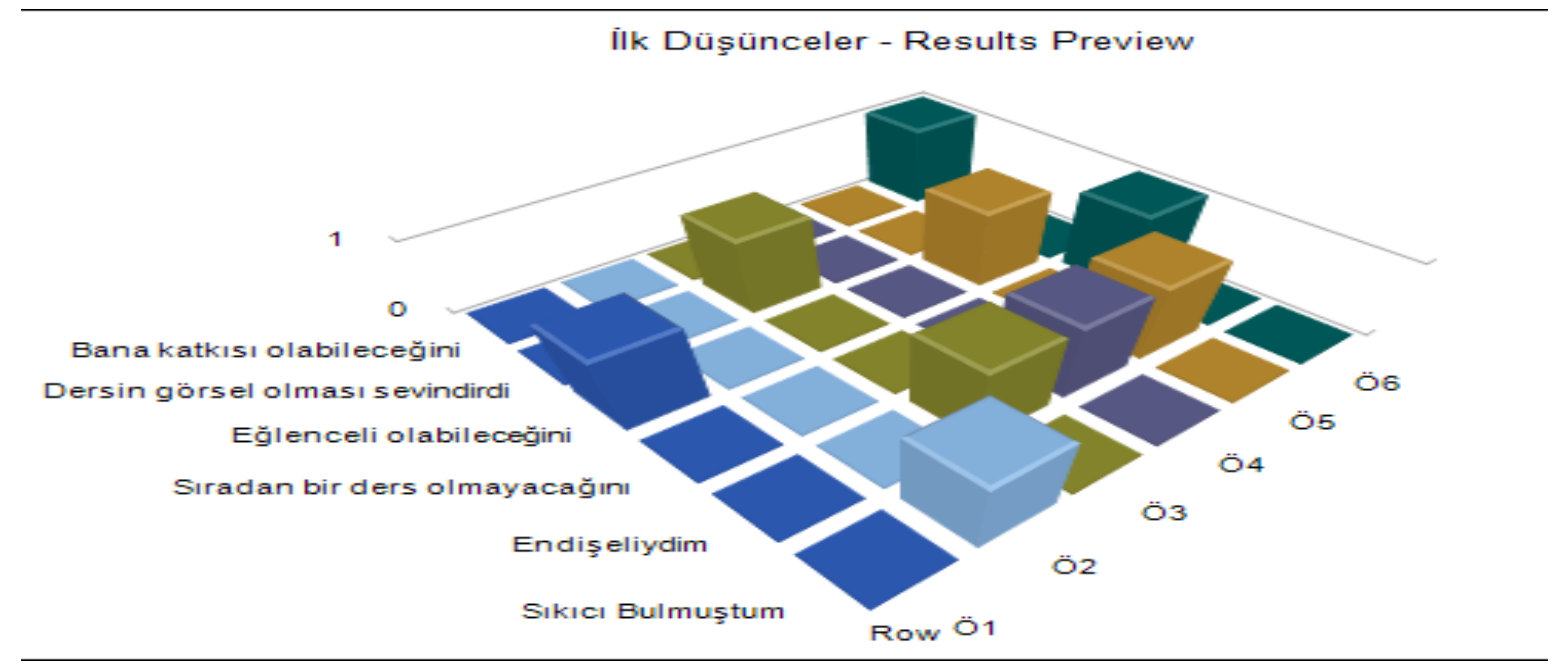

Grafik 1. Öğretmen adaylarınin kavram karikatürü destekli fen öğretimi laboratuvar uygulamaları hakkindaki ilk düşünceler

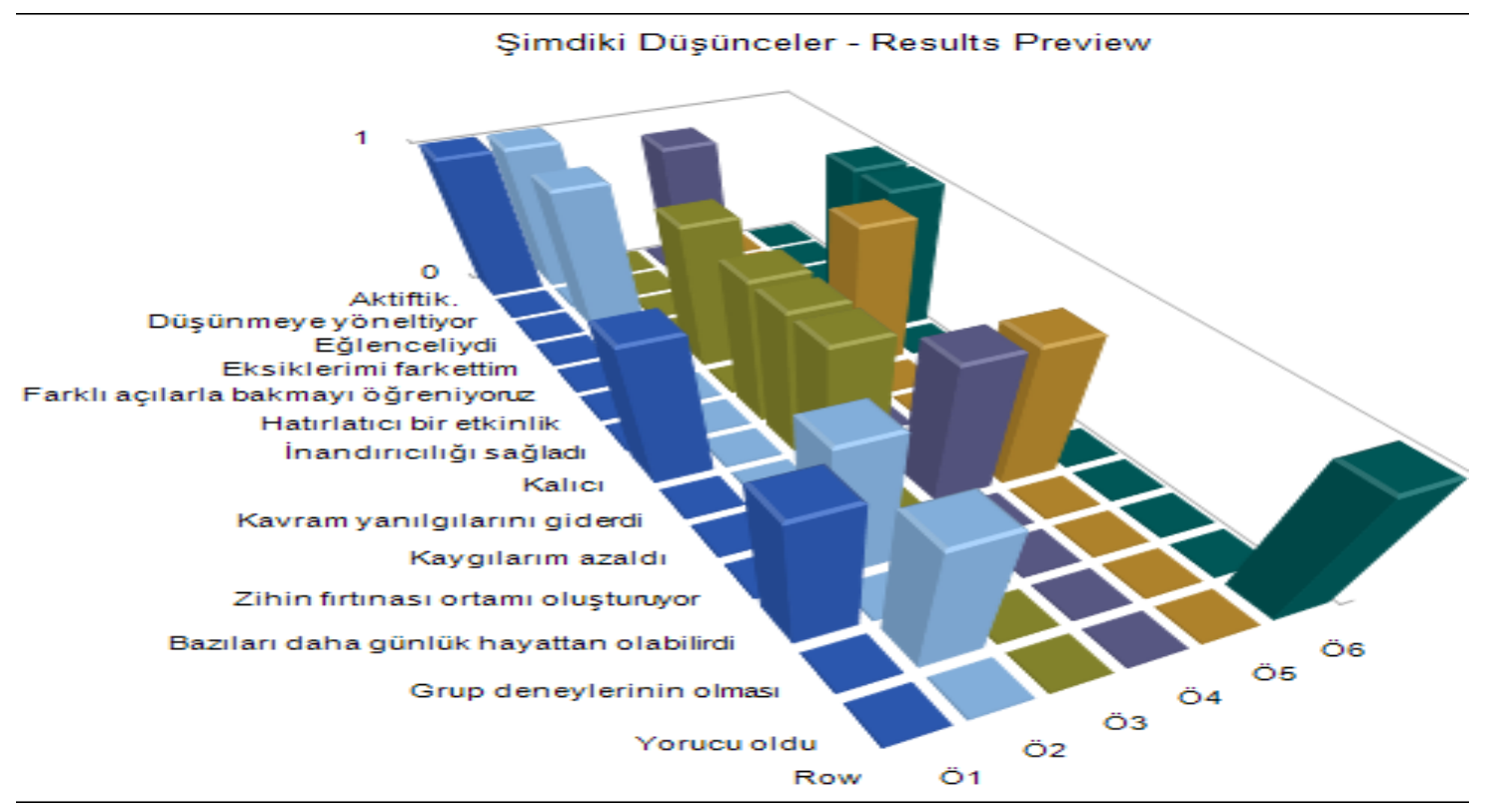

Grafik 2. Öğretmen adaylarınin kavram karikatürü destekli fen öğretimi laboratuvar uygulamaları hakkindaki şimdiki düşünceler

\section{İkinci Alt Probleme İlişkin Bulgular}

İkinci alt problemde fen bilgisi öğretmen adaylarının kavram karikatürü destekli fen öğretimi laboratuvarının kendi öğrenmeleri üzerindeki düşünceleri alınmıştır. Öğretmen adayları bu konudaki düşüncelerini kavram karikatürü destekli fen öğretimi laboratuvarı dersinin diğer derslerden farkını, öğrenmeye katkısı ve geliştirdiği kazanımlar şeklinde değerlendirerek ifade etmişlerdir. Bu nedenle bu üç başlıkta değerlendirilecektir. 
Kavram karikatürü destekli fen öğretimi laboratuvarı dersinin öğretmen adaylarının kendi öğrenmeleri üzerindeki düşüncelerine ait model Şekil 2' de verilmiştir. Şekil 2 incelendiğinde öğretmen adaylarının bu dersin diğer derslerden farkı için verdiği cevapların hepsinin olumlu düşüncelerden oluştuğunu görmekteyiz. Söylenen bu düşüncelerin sayısına dair grafik ise Grafik 3'te verilmiştir. Grafik 3'teki kavram karikatürü destekli yürütülen fen öğretimi laboratuvarı dersinin diğer derslerden farkı hakkındaki düşüncelerin sayısına bakıldığında öğretmen adaylarının çoğu kavram karikatürü destekli yürütülen fen öğretimi laboratuvarı dersinin diğer derslere göre daha akılda kalıcı bir ders olduğunu düşünmektedirler.

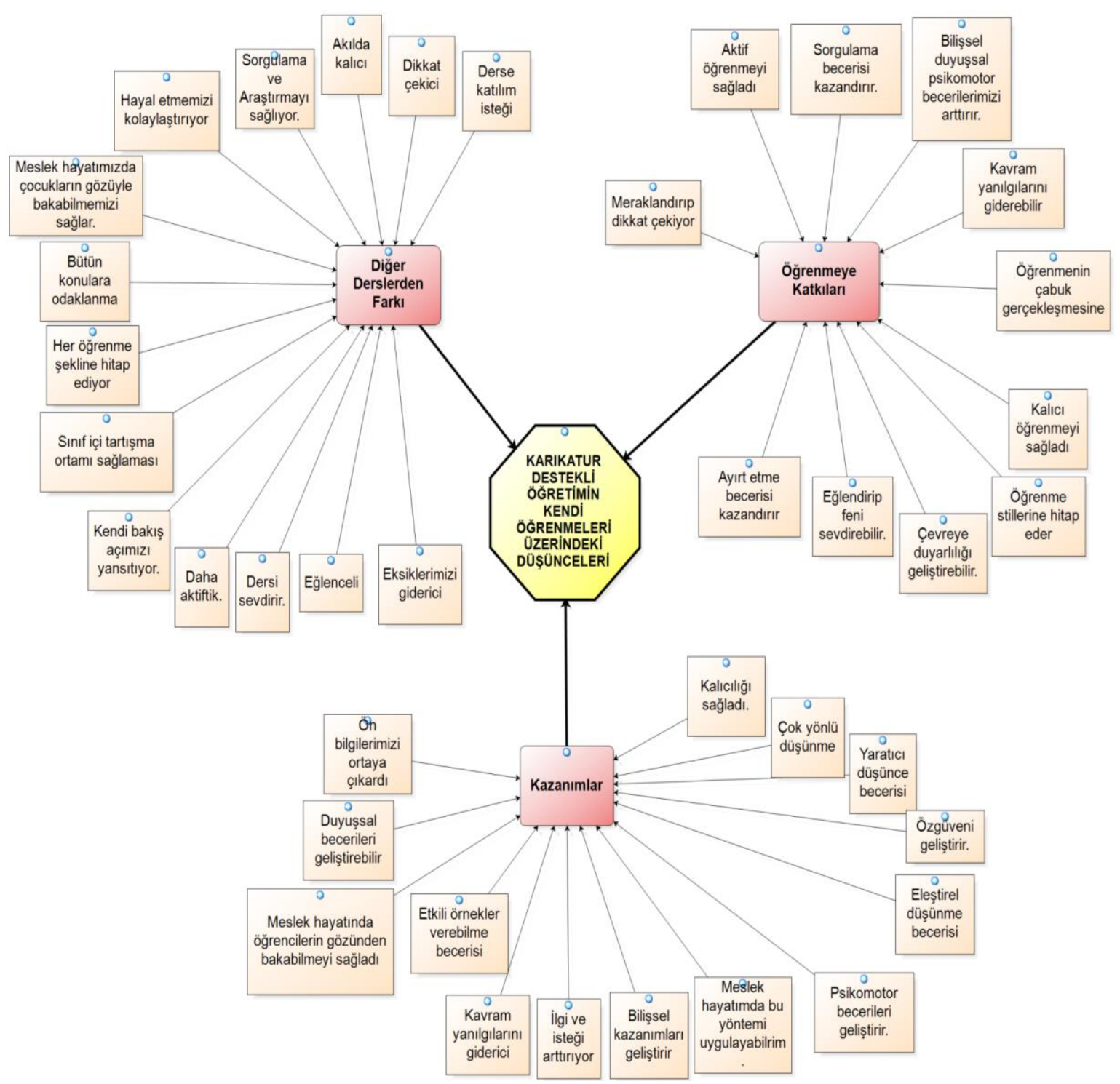

Şekil 2. Kavram karikatürü destekli fen öğretimi laboratuvarı dersinin öğretmen adaylarının kendi öğrenmeleri üzerindeki düşünceler 
Şekil 2'deki modele göre öğretmen adaylarının karikatür destekli fen öğretimi laboratuvarı dersinin öğrenmeye katkısı hakkındaki düşüncelerinin çok çeşitli başlıklar altında toplandığı görülmektedir. Karikatür destekli fen öğretimi laboratuvarı dersinin öğrenmeye katkıları hakkındaki düşünce sayısı Grafik 4'te gösterilmiştir. Grafik 4' teki veriler incelendiğinde öğretmen adaylarının çoğu kavram karikatürü destekli fen öğretimi laboratuvarı dersinin kalıcı öğrenmeyi sağladığını ifade ettiği görülmektedir. Grafik 3 ve Grafik 4' ten elde edilen veriler 1şığında öğretmen adaylarının kavram karikatürü destekli yürütülen fen öğretimi laboratuvarı dersinin hem diğer derslerden farkını ifade ederken hem de öğrenmeye katkılarını değerlendirirken özellikle "kalıcı öğrenme sağladı" düşüncesinde birleştikleri tespit edilmiştir.

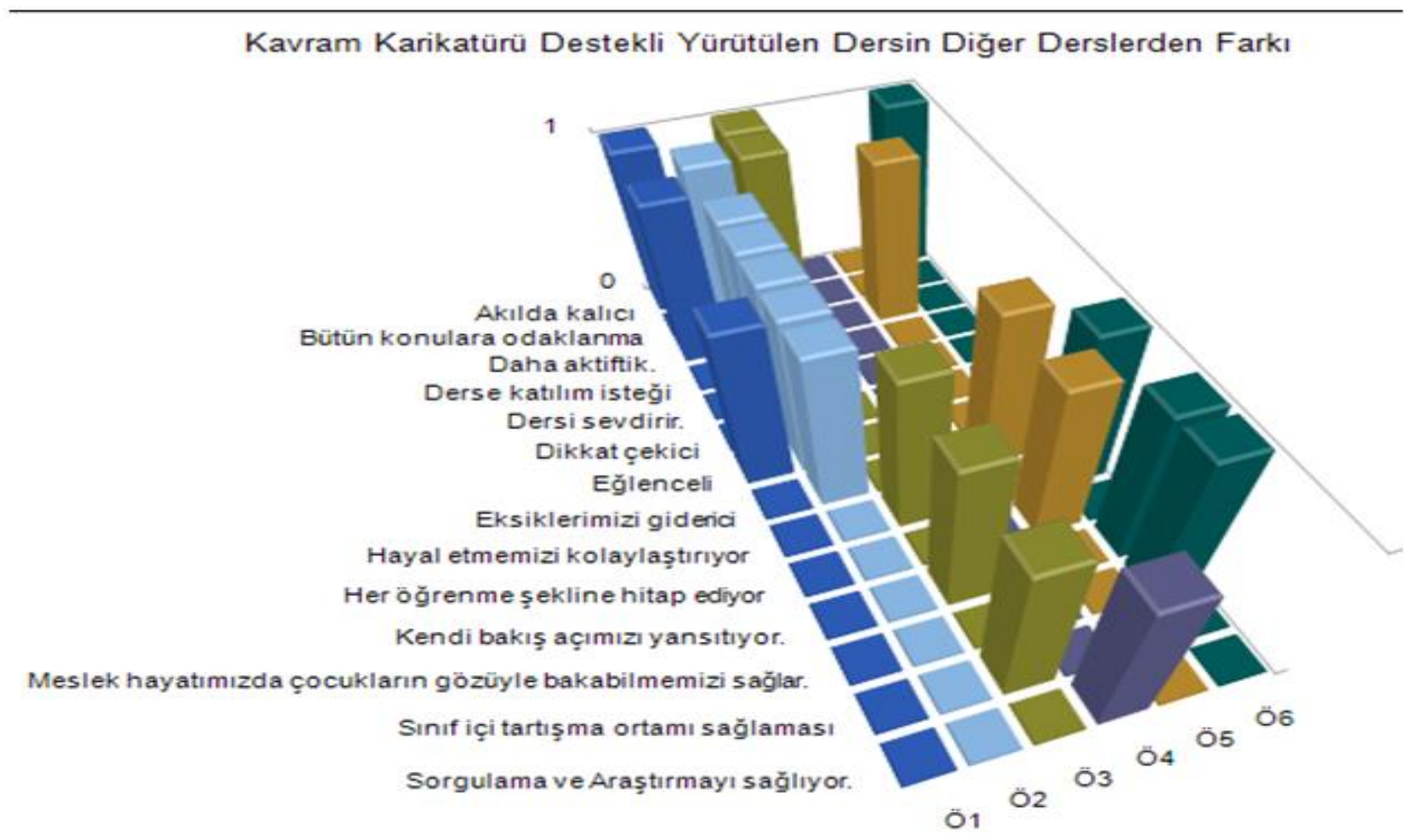

Grafik 3. Kavram karikatürü destekli fen öğretimi laboratuvarı dersinin diğer derslerden farkı hakkındaki düşünceler 


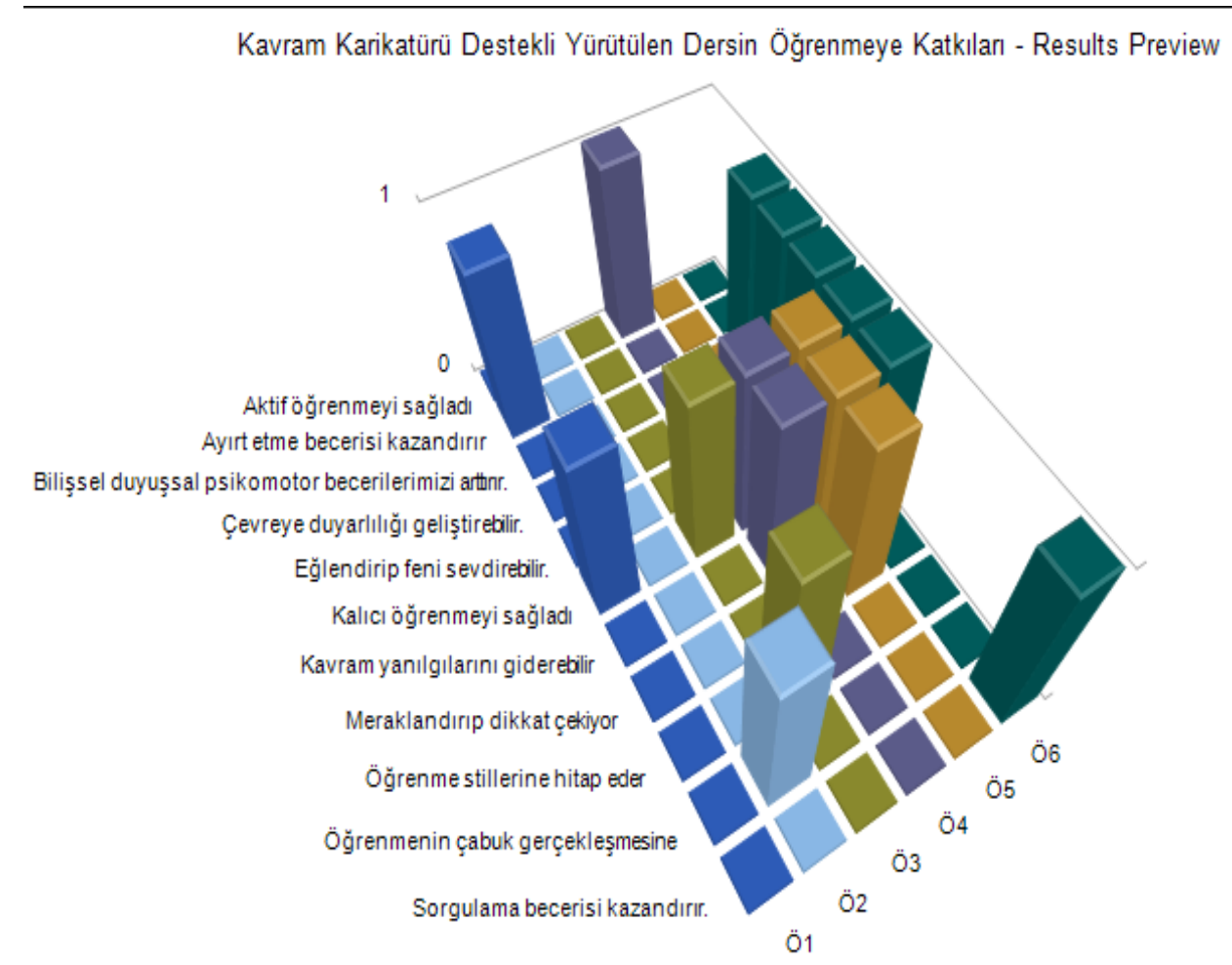

Grafik 4. Karikatür destekli fen ögretimi laboratuvarı dersinin ögrenmeye katkıları hakkındaki düşünceler

Kavram karikatürü destekli yürütülen fen öğretimi laboratuvarı dersinin geliştirdiği kazanımlarla ilgili düşünce sayısına ait grafik Grafik 5' de verilmiştir. Grafik 5'de görüldüğü üzere öğretmen adayları kavram karikatürü destekli yürütülen bu dersin en fazla psikomotor becerileri geliştirdiğini düşünmektedirler. Çoğunlukta söylenen diğer bir cevabın ise “...meslek hayatımda bu yöntemi uygulayabilirim.” cevabı olduğu görülmektedir. Çalışmanın ikinci alt problemine göre öğretmen adayları kavram karikatürü destekli fen öğretimi laboratuvarı dersinin kendi öğrenmeleri üzerine bilişsel, duyuşsal, psikomotor olarak pek çok olumlu etkileri olduğunu ifade etmişlerdir. Özellikle de bu alanlarda kalıcı öğrenmeyi sağladığını belirtmişlerdir. Öğretmen adaylarının ikinci alt probleme ilişkin bazı cevapları şöyledir:

Ö2: “Bu ders için konuşacak olursak bunda en başta dediğim gibi aktif olunca insanlarında genelde hani bizim sınıfimızda bu tarz dikkatimizi çektiği için sürekli aktif oluyor. Eğlenceli oluyor, daha çok katılmak istiyorlar ve ister istemez eksik yönlerimizi de kapatmış oluyoruz.......Bir de hocam orda birden fazla fikir var ya sinıfta mesela farklı görüşte insanlar var ve hepsi farklı bir görüşü şey yapıyor ve ister istemez sen fikrini söylediğin için kendine bir özgüvenin gelebiliyor....Şimdi hani deney yapıyorsak zaten 
Ege Eğitim Dergisi 2017 (18) 2: 738-773

Kavram Karikatürü Destekli Fen Öğretimi Hakkında Öğretmen Adaylarının Görüşleri

psikomotor var. Psikomotorda en temel zaten fende deneylerdir. Yaparak yaşayarak ögrenme mantığı altında o hani bu etkinlikte de biz üç tane fikrini söylüyor ama biz aynı zamanda onun deneyini uyguluyoruz etkinliğin sonunda...."

Ö5: "Başta ders süreci boyunca etkin oluyoruz. Çünkü ilk başta kendi düşüncemizi yazdı̆̆ımız bölüm var, sonra açıklama bölümü var, daha sonra deney bölümü var. Hani bunların için hep aktif bir şekilde ilerliyor dersi. .....̈̈̆grenmeyee.... İşte merak duygusu uyandırıyor. ...kavram kargaşasını giderememişim ama orada karakterler söyleyip çelişki yaşadıklarında arkadaşlarımız bu sefer tartışma ortamı oldu ve daha kalıcı olduğuna inanıyor arkadaşlar hani. Çünkü bunun sınıfta şakası bile yapıldı siz karakteriyle birlikte....Bence ilkönce duyuşsal kazandırır..... Eee..duyuşsalda hani yaptığımız deneylerin bir çoğu hani zaten çevremizle ilgili olduğu için biraz hani dikkat ediyoruz ve önemli olduğunu anlıyoruz..... Psikomotor zaten deney yapıyoruz. O yönden kazandırıyor.”

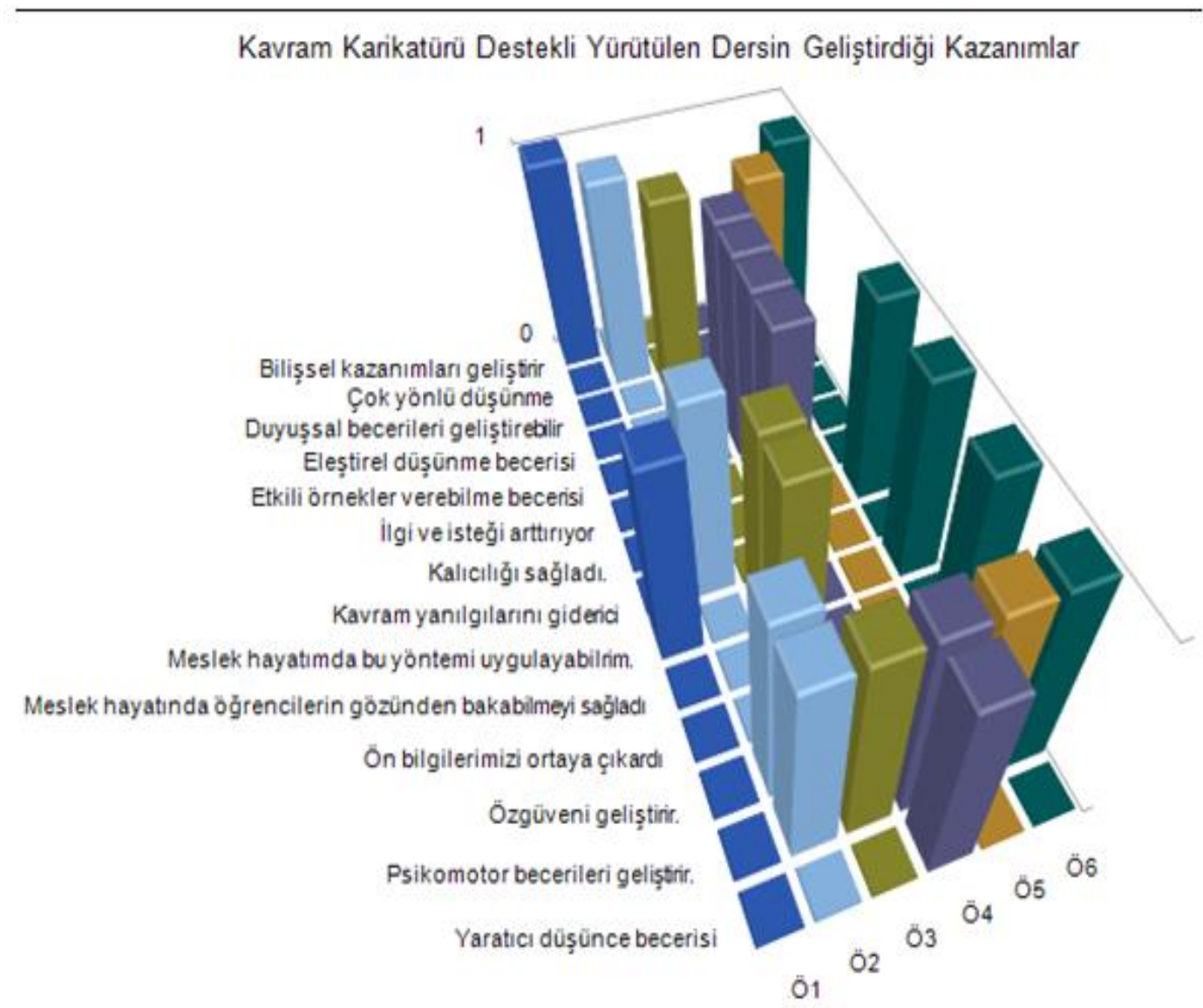

Grafik 5. Kavram karikatürü destekli yürütülen fen öğretimi laboratuvarı dersinin geliştirdiği kazanımlarla ilgili düşünceler 


\section{Üçüncü Alt Probleme İlişkin Bulgular}

Çalışmanın üçüncü alt probleminde ise fen bilgisi öğretmen adaylarının kavram karikatürü destekli fen öğretimi laboratuvarının etkili olabilmesi konusundaki önerileri ve bu önerilere dair model Şekil 3'de sunulmuştur. Şekil 3 incelendiğinde fen bilgisi öğretmen adayları kavram karikatürü destekli öğretimin daha etkili olabilmesi için önerilerini dersin hangi bölümünde kullanılması ve öğretimin daha etkili olması için neler yapılması gerektiği şeklinde iki başlıkta ifade etmişlerdir. Bu nedenle öğretmen adaylarının önerileri bu iki başl1kta değerlendirilecektir.

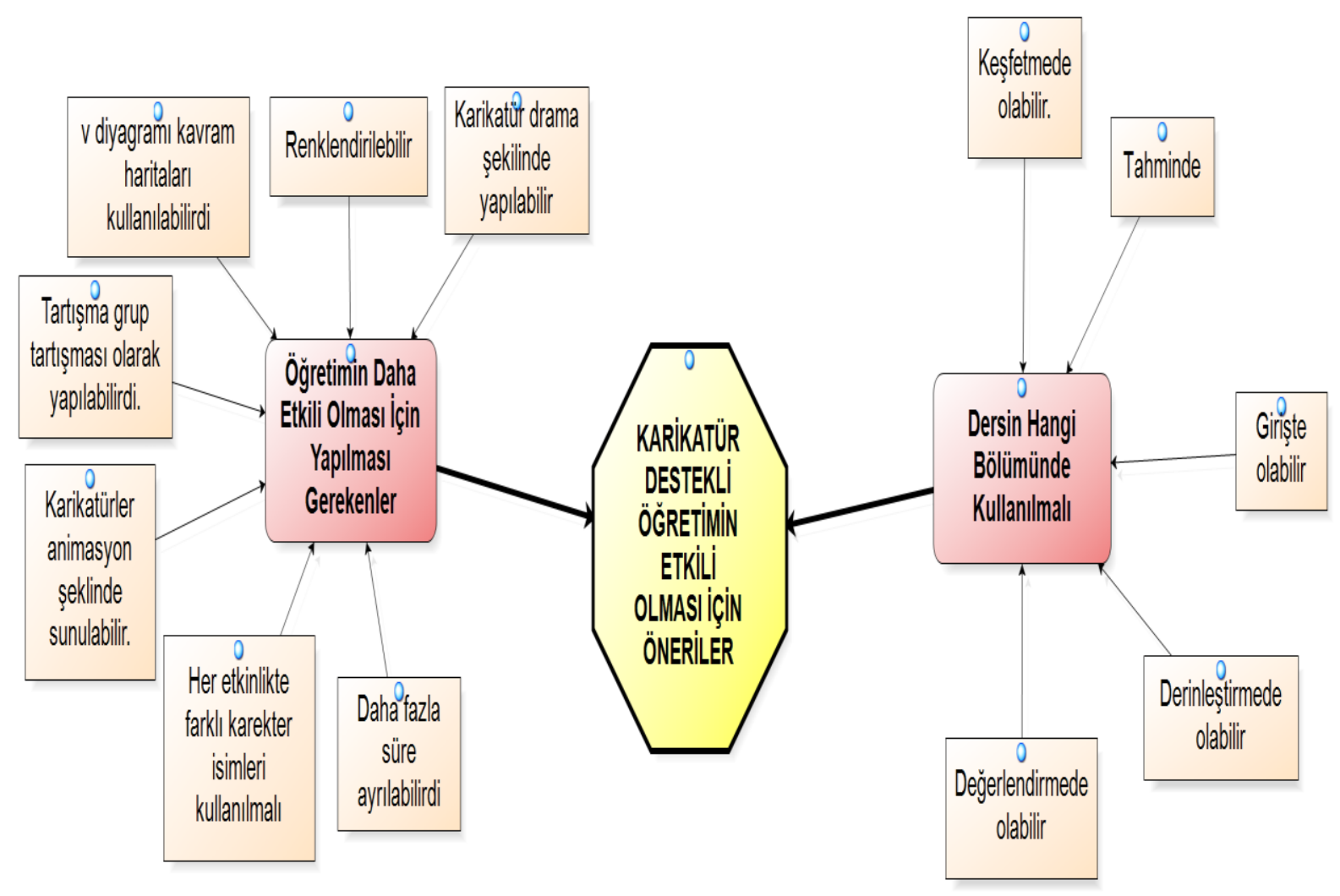

Şekil 3. Kavram karikatürü destekli fen öğretimi laboratuvarının etkili olabilmesi konusundaki öneriler

Kavram karikatürü destekli yürütülen fen öğretimi laboratuvarı dersinin daha etkili olabilmesi için dersin hangi bölümünde kullanılması gerektiğine dair düşünce sayısına ait Grafik 6'da verilmiştir. Grafik 6 incelendiğinde öğretmen adayları kavram karikatürlerinin dersin hangi bölümünde kullanılması gerektiğine dair farklı önerilerde bulunmuşlardır. Ancak öğretmen adaylarının yaptığı bu önerilerin daha çok dersin tahmin aşamasında kullanılması gerektiği düşüncesinde birleştiği görülmektedir. 
Kavram karikatürü destekli yürütülen fen öğretimi laboratuvarı dersinin daha etkili olabilmesi için yapılması gerekenler konusundaki öğretmen adaylarının düşünce sayısına ilişkin grafik ise Grafik 7'de verilmiştir. Grafik 7'de ise öğretmen adayları kavram karikatürü destekli fen öğretimi laboratuvarının daha etkili olabilmesi için en çok karikatürlerin animasyon ya da renkli şeklinde sunulması gerektiği yönünde görüşlerini ifade etmişlerdir. Üçüncü alt problemle ilgili öğretmen adaylarının bazı cevapları şöyledir:

Ö1: “Hocam bence derinleştirme de .... a aşama mesela çünkü bir açıklama filan yaptıktan sonra kavram hani hataları düzeltmemiz bu konuda rahat olmaz mı? Çocuk çok eğlenceli bir şey yapıyor hani orda çok rahat.... Bence orda daha çok öğrencinin hatalarını, kavram hatalarını daha çabuk yakalarsınız gibi geliyor."

Ö3: "Tahminde bence iyi olmuş. Çünkü o resimlere bakarak tahmin daha iyi gelişir. Yani düşünceleri ve yorumları daha iyi gelişir, pekişir. İyi olmuş bence. Bu karikatürleri ĕger diğer kısımlarda ve ya sonuçta verilseydi öğrencinin dikkatini çekmezdi. Çünkü tahmin etmek için düşünürsün ona bakarsın daha fikirler öyle gelişir. Sonuçta etkili olmazdl bence....Renklendirilebilir, farklı şekiller kullanılabilir. Şimdi biraz çocukça olacak ama çiçek ya da baloncuklar kullanılabilir."

Ö6: "Giriş bölümünde olmall. Çünkü 5E modelindeki ilk giriş çok önemli bir ders için ya da insanları etkileme açısından her anlamda bu hani aslında çok önemli. Giriş bölümünde olmalı...Hani ölçme değerlendirme olarak da verilebilir bir karikatür...Mesela tamam yaptık hani deneyi gördük konuyu da anlattını ama oradaki soruyu böyle sorması bu sefer bizim konuyu kavrayıp kavramadığımızdı da gösterir. Bu da ölçme babından iyi olur...Daha renkli kullanılabilirdi mesela oradaki karikatürler. Görsele önem verilmeliydi renk bakımından... Bir de renkli ve daha güzel bir çizim olsaydı daha çok dikkat çekerdi. 
Ege Eğitim Dergisi 2017 (18) 2: 738-773

Kavram Karikatürü Destekli Fen Öğretimi Hakkında Öğretmen Adaylarının Görüşleri

Dersin Hangi Bölümünde Kullanılması Gerektiğine İlişkin Öneriler - Results Preview

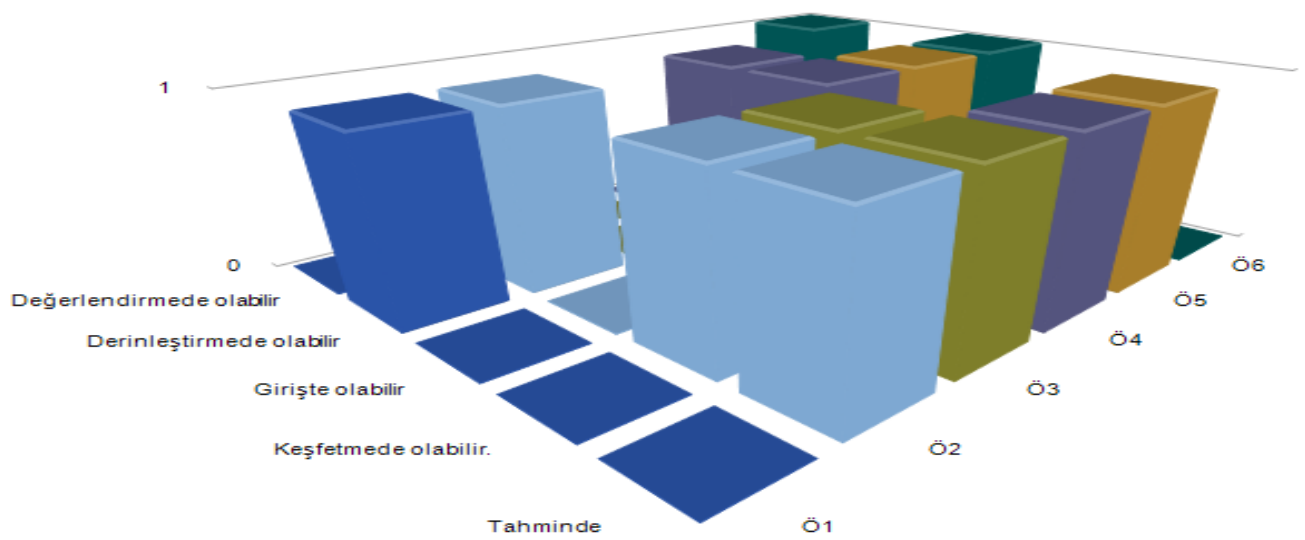

Grafik 6. Kavram karikatürü destekli fen ögretimi laboratuvarı dersinin daha etkili olabilmesi için dersin hangi bölümünde kullanılması gerektiğine dair düşünceler

Kavram Karikatürü Destekli Yürütülen Fen Öğretimi Laboratuvarı Dersinin Daha Etkili Olması İçin Neler Yapılabilir

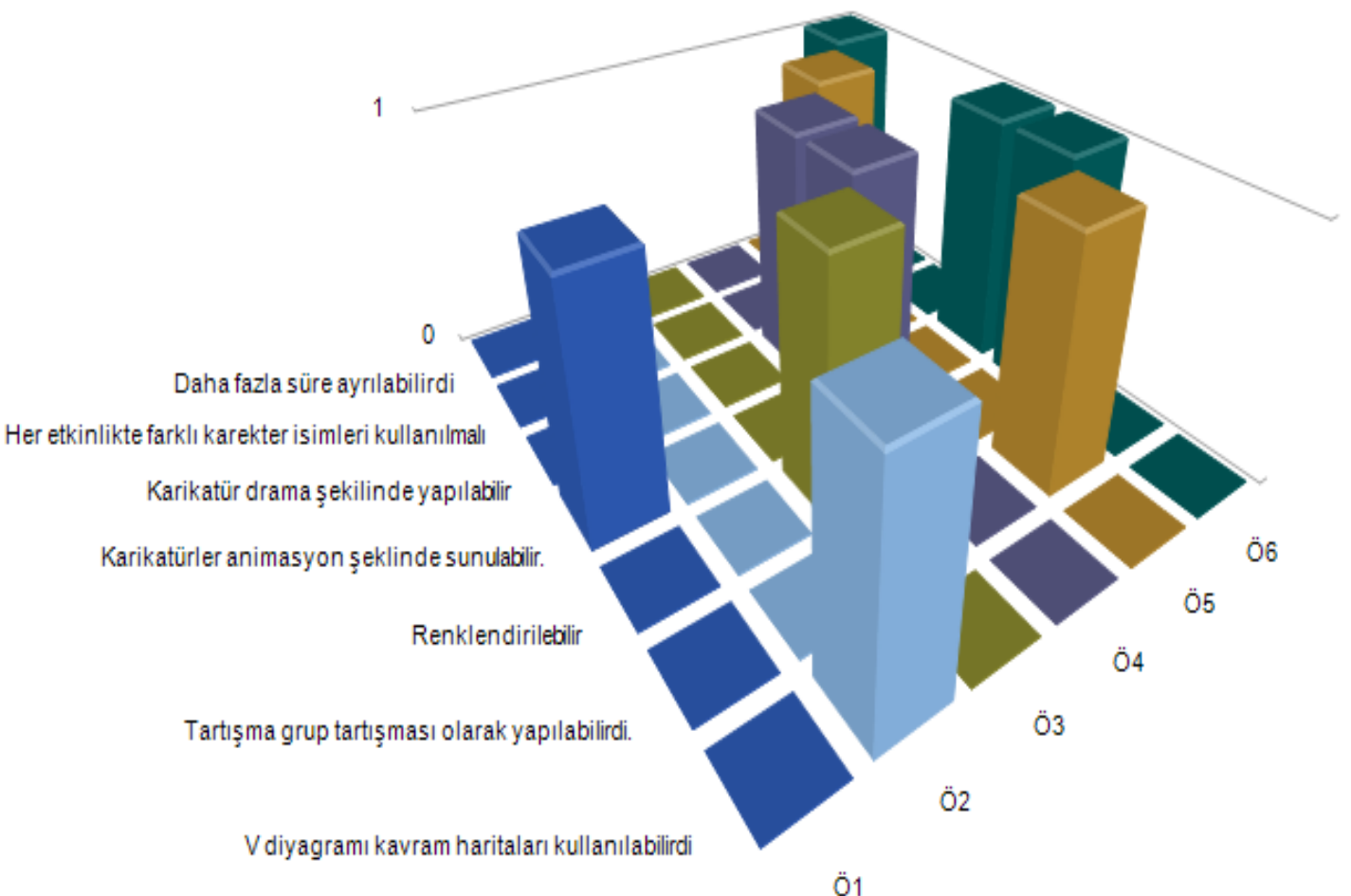

Grafik 7. Kavram karikatürü destekli fen ögretimi laboratuvarı dersinin daha etkili olabilmesi için yapılması gerekenler konusundaki düşünceler 


\section{Tartışma ve Yorum}

Kavram karikatürü destekli yürütülen fen öğretimi laboratuvarı dersi hakkında fen bilgisi öğretmen adaylarının görüşlerini almayı amaçlayan bu araştırmanın birinci alt probleminde derse yönelik genel düşünceler alınmıştır. Fen bilgisi öğretmen adayları ders hakkındaki genel düşüncelerini, öğretimin kavram karikatürü destekli yapılacağını öğrendiklerinde oluşan ilk düşünceleri ve öğretim gerçekleştirildikten sonra ders hakkında şimdiki düşünceleri şeklinde ifade ettikleri görülmektedir. Elde edilen verilere göre öğretmen adaylarının ders hakkındaki ilk düşünceleri ile şımdiki düşünceleri karşılaştırıldığında hem ilk düşüncelerinde hem de şimdiki düşüncelerinde olumlu düşüncelerin daha fazla olduğu görülmektedir. Dolayısıyla kavram karikatürleri fen bilgisi öğretmen adaylarının yetiştirilmesinde kullanılabilir. Nitekim alan yazınındaki bazı çalışmalarda öğretmen adaylarının yetiştirilmesinde kavram karikatürlerinin kullanıldığını görmekteyiz (Birişçi ve diğ., 2010; Cengizhan, 2011). Ancak bahsi geçen çalışmaların fen eğitimine yönelik olmadığı görülmüştür. Bu çalışmadan elde edilen veriler 1şığında geliştirilen kavram karikatürlerinin öğretmen adaylarının fen öğretiminde kullanılması ile olumlu sonuçlar elde edileceği söylenebilir. Bu sonuçların tespit edilmesi için kavram karikatürlerinin fen bilgisi öğretmen adaylarının fen öğrenimi üzerine etkilerini inceleyen çalışmalar arttırılabilir. Yüksek öğretimde kavram karikatürü kullanımına yönelik yapılan literatür taraması sonucunda öğretmen adaylarının fen öğrenimi için geliştirilen herhangi bir kavram karikatürüne rastlanmamıştır. $\mathrm{Bu}$ çalışmada öğretmen adaylarının fen öğrenimine yönelik kavram karikatürleri geliştirildiği için özgün bir çalışma olduğu düşünülmektedir.

Öğretmen adaylarının ders hakkındaki genel düşüncelerinde olumlu düşünce olarak en fazla, derste daha aktif olduklarını, farklı açılardan bakmayı öğrendiklerini, kalıcı olduğunu ve ders ile ilgili kaygılarının azaldığını belirtmişlerdir. Kavram karikatürü ile ilgili yapılan pek çok çalışmanın sonuçları da öğretmen adaylarının bu görüşlerini destekler niteliktedir (Balım, İnel, Evrekli ve Kesercioğlu, 2008; Balım, Ormancı ve diğ., 2016; Birişci ve diğ., 2010; Durmaz, 2007; Kinchin, 2004, akt. Şaşmaz-Ören, 2009; Long ve Marson, 2003, akt. Şaşmaz-Ören, 2009; Özalp, 2006;Özüredi, 2009; Say, 2011).

Çalışmada öğretmen adaylarının olumsuz düşüncelerinin de olduğu tespit edilmiştir. Özellikle öğretmen adaylarının pek çoğu kavram karikatürü destekli öğretim gerçekleştirilmeden önce endişeli olduklarını belirtmişlerdir. Fakat bu cevabı veren adayların çoğu ilerleyen zamanlarda endişelerinin azaldığını ifade etmişlerdir. Bu nedenle öğretmen 
adaylarının kavram karikatürü destekli yürütülen fen öğretimi laboratuvarı dersi ile ilgili şimdiki düşüncelerinde özellikle olumlu düşüncelerdeki artışın daha fazla olduğu görülmektedir. Ayrıca uygulama sonrasında belirttikleri olumlu ve olumsuz düşünce sayısının uygulama öncesinde belirttikleri düşünce sayısından daha fazla ve düşüncelerini daha ayrıntılı açıkladıkları görülmüştür. Böyle bir sonucun ortaya çıkmasında başlangıçta öğretmen adaylarının dersin nasıl olacağı ile ilgili merak duygusunu endişe şeklinde adlandırmaları düşünülebilir. Nitekim öğretmen adaylarının derse kaygılı yaklaşmasını laboratuvar derslerinin uygulamalı bir ders olması, kendine özgü yapısı, ortam, malzemeler, deneylerin yalnız ya da grup ile yaparken alınan sorumlulukların olması gibi nedenlere de bağlanabilir (Uşaklı ve Akpınar, 2015). Çünkü endişeli olduğunu ifade eden pek çok öğretmen adayı "... bir ön yargımız oldu.... ama sonradan hani artık yapabileceğine inanıyorsun.....", "....o deneyleri yaptıktan sonra, o karikatür şeyini doldurduktan sonra bu endişem kesinlikle gitti..." şeklinde cevaplar vermişlerdir. Dolayısıyla verilen bu cevaplardan hareketle kavram karikatürü destekli fen eğitimi öğretmen adaylarının fen'e ya da fen öğretimine yönelik motivasyon ve tutumlarını olumlu yönde etkileyebilir. Nitekim İzgi (2012) tarafından yapılan bir çalışmada kavram karikatürüne dayalı öğretimin öğretmen adaylarının fen'e karşı tutumlarını olumlu yönde etkilediği tespit edilmiştir. Bu konuda literatürdeki çalışmalar araştırıldığında karikatürlerin derse yönelik tutum ve endişeye etkisini inceleyen çalışmaların az olduğu görülmektedir (Baysarı, 2007; Çiçek, 2011; Greenwald ve Nestler, 2004; İzgi, 2012; Köklükaya ve diğ., 2016; Rule ve Auge, 2005). Yapılan bu çalışmalarının sonuçlarına bakıldığında karikatürlerin derse yönelik tutum ve endişeye etkisinin birbirinden farklı olduğu görülmektedir. Ayrıca fen derslerinde kavram karikatürü kullanım örnekleri ve kavram karikatürlerine yönelik öğrenci ve öğretmen görüşlerinin alınması amacıyla Balım, Ormancı, Evrekli, Kaçar ve Türkoğuz (2016) tarafından yapılan çalışmada öğrencilerin kavram karikatürlerinin sınıf ortamını eğlenceli hale getirdiği belirtilmiştir. $\mathrm{Bu}$ yolla derse olan ilgi ve tutumu arttırabileceği, günlük yaşamla ilişki kurma gibi bilişsel ve duyuşsal gelişme sağlanabileceği öngörülmekte; ancak bu durumun bilimsel gerçeklilik kazanması için kavram karikatürlerinin bilişsel ve duyuşsal beceriler üzerindeki etkilerini inceleyen çalışmaların arttırılması gerektiği belirtilmektedir.

Araştırmanın ikinci alt probleminde öğretmen adayları kavram karikatürü destekli fen öğretimi laboratuvarı dersinin kendi öğrenmeleri üzerine etkisi araştırılmıştır. $\mathrm{Bu}$ alt probleme yönelik sorulan sorularda öğretmen adaylarının çoğu bu dersin diğer derslere göre daha akılda kalıcı olduğunu, kalıcı öğrenmeyi sağladığını ve kavram yanılgılarını giderdiğini 
belirtmişlerdir. $\mathrm{Bu}$ anlamda, kavram karikatürü destekli öğretimin öğretmen adaylarının bilişsel gelişimini sağladığı söylenebilir. Fen eğitiminde kavram karikatürü ile ilgili yapılan bazı çalışmalar bu sonucu desteklemektedir (Balım ve diğ., 2008; Ekici ve diğ., 2007; Kabapınar, 2005; Saka, Akdeniz, Bayrak ve Asilsoy, 2006, akt. Balım, Ormancı ve diğ., 2016). Yine bu alt probleme yönelik sorulan başka sorularda ise öğretmen adayları meslek hayatlarında bu yöntemi kullanabileceklerini ve kavram karikatürü destekli fen öğretiminin en çok psikomotor becerileri geliştirdiğini ifade etmişlerdir. Meslek hayatlarında bu yöntemi kullanabileceklerini ifade etmeleri öğretmen adaylarında fen öğretiminde kavram karikatürünü kullanımına yönelik olumlu bir tutum kazandırdığını ve duyuşsal bir gelişim olduğunu da göstermektedir. İngiltere'de yapılmış olan "Kavram Karikatürü Kullanılarak Oluşturmacı Bir Ölçme" adlı çalışmadan elde edilen bulgular araştırmanın bu sonucunu destekler niteliktedir. Keogh, Brenda, Naylor ve Stuart' in (1999) yaptığı bu çalışmada eğitiminde kavram karikatürü kullanılan fen öğretmeni adayları veya onlarla görevlerinin ilk yıllarında yapılan bazı çalışmalarda sahip oldukları negatif tutumu azaltmada, kavram karikatürlerinin kullanımı bilimsel alt yapılarının yeniden düzenlenmesine ve sınıftaki öğrenme ve öğretme ortamı, ölçme değerlendirme yaklaşımları için olumlu katkıları olmuştur (Akt. Çetin, 2012).

Kavram karikatürü destekli fen öğretimi laboratuvarı dersinin daha etkili olması için yapılması gerekenler hakkında öğretmen adaylarının görüşlerinin alındığı üçüncü alt problemden elde edilen bulgular incelendiğinde öğretmen adayları bu konuyu kavram karikatürlerinin dersin hangi aşamasında kullanılması gerektiği ve bu dersin daha etkili olabilmesi için yapılması gerekenler şeklinde değerlendirmişlerdir. Öğretmen adaylarının çoğu kavram karikatürlerinin tıpkı derste uygulandığ 1 şekliyle tahmin aşamasında kullanılması yönünde, dersi 5E modeline göre değerlendiren öğretmen adaylarının çoğu ise giriş veya derinleştirme aşamalarında kullanılması gerektiğini ifade etmişlerdir. 5E modeline göre değerlendirme yapan öğretmen adayları karikatürlerin dikkat çektiği ve sınıf içi tartışmaya yönelterek tahminlerde bulunmaya sevk ettiği için kullanılabileceğini belirtmişlerdir. Özyılmaz-Akamca ve Hamurcu'nun (2009) "Analojiler, Kavram Karikatürleri ve Tahmin-Gözlem-Açılama Teknikleriyle Desteklenmiş Fen ve Teknoloji Ĕ̆itimi" isimli çalışmasında TGA yöntemi ile gerçekleştirilen fen öğretiminde kavram karikatürlerinin tahmin aşamasında kullanılması öğrencilerin ön fikirlerini ortaya koymada, konuya ilgilerini çekmede etkili olduğu öngörülmektedir. Öğretmen adayları kavram karikatürü destekli gerçekleştirilen bu dersin daha etkili olabilmesi için çok çeşitli görüşler 
sunmuştur. Ancak bu görüşlerin daha çok kavram karikatürlerinin animasyon şeklinde sunulması ve görsel olarak renklendirilmesi gerektiği yönünde yoğunlaştığını görmekteyiz. Evrekli ve Balım (2015) tarafından fen derslerinde animasyon destekli kavram karikatürü kullanımının altıncı sınıf öğrencilerinin sorgulayıcı öğrenme becerilerine etkisinin araştırıldığı deneysel çalışmada iki deney grubu bir de kontrol grubu kullanılmıştır. Birinci deney grubuna animasyon destekli kavram karikatürleri ve fen ve teknoloji öğretim programı, ikinci deney grubuna sadece kavram karikatürleri, kontrol grubunda ise fen ve teknoloji öğretim programı ile dersler işlenmiştir. Çalışmanın sonucunda grupların sorgulayıcı öğrenme becerileri algı puanları arasında anlamlı bir farklılık gözlenmezken, animasyon destekli kavram karikatürü kullanılan deney grubunun ön test ve son test puanları arasında yüksek düzeyde anlamlı bir puan farklılığı olduğu görülmüştür. Dolayısıyla kavram karikatürlerinin renklendirilmesi ya da animasyonlarla desteklenmeleri öğrencilerde anlatılan olayın daha iyi algılanmasına ve sorgulama becerisini geliştirebileceği söylenebilir.

\section{Sonuç ve Öneriler}

Araştırma sonucunda elde edilen veriler incelendiğinde kavram karikatürü destekli fen öğretimi hakkında öğretmen adayları ders öncesinde kaygılarının olduğunu ancak bu kaygıların dersten sonra azaldığı, kavram karikatürü destekli gerçekleştirilen fen öğretimi dersinin bilgilerin kalıcılığını sağlandığı ve kavram yanılgılarının giderdiğini ifade etmişlerdir. Kavram karikatürleri ilk olarak bir grup ilköğretimdeki öğretmenlerin aldığ1 hizmet içi eğitim kursları sırasında ortaya çıkmıştır (Naylor ve Keogh, 1999, akt. Durmaz, 2007). Çalışma grubundaki öğretmen adaylarının kavram karikatürü destekli yürütülen fen öğretimi hakkındaki görüşlerinden hareketle kavram karikatürlerinin öğretmen eğitiminde kullanılmasından olumlu sonuçlar elde edileceği söylenebilir. Bununla birlikte fen öğretimi laboratuvarı uygulamaları dersinde fen bilgisi öğretmen adayları kavram karikatürlerinin uygulamaya dönük haliyle ilk defa tanıştıkları için ileride meslek hayatlarında bu derste edindikleri tecrübeleri kendi öğrencilerinde kullanacaklarını belirtmişlerdir. Bütün bu veriler ışığında, fen eğitiminde kavram karikatürlerinin kullanımı öğretmen adaylarının fen'e ve fen eğitimine yönelik motivasyonlarını, tutumlarını ve başarılarını olumlu yönde etkileyebilir. Ayrıca öğretmen adaylarının derse yönelik motivasyon durumlarının artması bütün becerilerini olumlu etkilemekle birlikte daha çok psikomotor becerilerin gelişmesini sağlamıştır. Yürütülen çalışmanın sonuçlarına bağlı geliştirilen öneriler aşağıdaki gibidir: 
- Fen öğretimi laboratuvarı uygulamaları dersi, öğretmen adaylarına fen kavramlarını ve akademik bilgileri kazandırması ile birlikte fen öğretiminin nasıl gerçekleştirildiğini kazandırmayı amaçlamaktadır. Bu nedenle eğitim fakültelerinde fen öğretimi laboratuvarı uygulamaları dersinde kavram karikatürlerinin kullanımı ile birlikte, fen eğitiminde farklı özel öğretim yöntemlerinin uygulamaları gösterilerek öğretmen adaylarının özel öğretim yöntemleri hakkındaki bilgilerinin sadece teori de kalmayıp pratik uygulamaları da gösterilebilir.

- Kavram karikatürleri ile gerçekleştirilen pek çok çalışmanın ilkokul ve ortaokul düzeyinde gerçekleştirdiğini görmekteyiz. Bu duruma karikatürlerin yapısı gereği genellikle ilkokul ve ortaokul yaş seviyesine uygun olduğu düşünülmesi etkili olabilir. Ancak fen'e yönelik kaygının azalması ve olumlu tutumların gelişebilmesi için eğitimin her yaş seviyesi ve öğretim düzeyi kavram karikatürlerden faydalanmalıdır.

- Kavram karikatürleri ile ilgili yapılacak çalışmalarda kavram karikatürlerinin derse yönelik tutum ve endişe düzeyi üzerine etkileri araştırılabilir. 


\section{Kaynakça}

Aydın, G. (2015). The effects of computer-aided concept cartoons and outdoor science activities on light pollution. International Electronic Journal of Elementary Education, 7(2), 142-156.

Bakanay, Ç. D. ve Çakır, M. (2016). Phenomenology and its reflections on science education research. International Online Journal of Educational Sciences. 8(4), 161-177.

Balım, A. G., İnel, D., Evrekli, E. ve Kesercioğlu, T. (2008, Eylül). The use of concept cartoons in constructive science and technology education: "The examples about the subject of pressure”. XIII. IOSTE Symposium, The Use of Science and Technology Education for Peace and Sustainable Development, Kuşadası.

Balım, A. G., İnel, D. ve Evrekli, E. (2008). Fen öğretiminde kavram karikatürü kullanımının öğrencilerin akademik başarılarına ve sorgulayıcı öğrenme becerileri algısına etkisi. İlkögretim Online, 7(1), 188-202.

Balım, A. G., İnel-Ekici, D. ve Özcan, E. (2016). Concept cartoons supported problem based learning method in middle school science classrooms. Journal of Education and Learning, 5(2), 272-284.

Balım, A. G., Ormancı, Ü., Evrekli, E., Kaçar, S. ve Türkoğuz, S. (2016). Fen derslerinde kavram karikatürü kullanım örnekleri ve kavram karikatürlerine yönelik öğrenci ve öğretmen görüşleri. Abant İzzet Baysal Üniversitesi Eğitim Fakültesi Dergisi, 16(3), 773-791.

Baysarı, E. (2007). Illköğretim düzeyinde 5. sinıf fen ve teknoloji dersi canlılar ve hayat ünitesi öğretiminde kavram karikatürü kullanımının öğrenci başarısına, fen tutumuna ve kavram yanılgılarının giderilmesine olan etkisi. (Yayımlanmış yüksek lisans tezi), Dokuz Eylül Üniversitesi Eğitim Bilimleri Enstitüsü, İzmir.

Bilen, K. ve Köse, S. (2012). Kavram öğretiminde etkili bir strateji TGA (Tahmin et-gözleaçıkla). Mehmet Akif Ersoy Üniversitesi Eğitim Fakültesi Dergisi, 1(24), 21-42.

Birişçi, S., Metin, M. ve Karakaş, M. (2010). Pre-service elementary teachers' views on concept cartoons: A sample from Turkey. Middle-East Journal of Scientific Research, 5(2), 91-97. 
Böyük, U., Demir, S. ve Erol, M. (2010). Fen ve teknoloji dersi öğretmenlerinin laboratuvar çalışmalarına yönelik yeterlik görüşlerinin farklı değişkenlere göre incelenmesi. TÜBAV Bilim Dergisi, 3(4), 342-349.

Büyüköztürk, Ş., Kılıç- Çakmak, E., Akgün,Ö., E., Karadeniz, Ş. ve Demirel, F. (2016). Bilimsel araştırma yöntemleri. (21. Baskı). Ankara: Pegem Akademi.

Cengizhan, S. (2011). Modüler öğretim tasarımıyla entegre edilmiş kavram karikatürleri hakkında öğretmen adaylarının görüşleri. Eğitim ve Bilim, 36(160), 93-103.

Çetin, E. (2012). Karikatürler ile zenginleştirilmiş fen ve teknoloji dersinin öğrenci başarısı ve tutumları üzerine etkisi. (Yayımlanmış yüksek lisans tezi), Selçuk Üniversitesi Eğitim Bilimleri Enstitüsü, Konya.

Çiçek, T. (2011). İlköğretim 6. sınıffen ve teknoloji dersinde kavram karikatürlerinin öğrenci başarısına, tutumuna ve kalıcılı̆̆a etkisi. (Yayımlanmış yüksek lisans tezi), Celal Bayar Üniversitesi, Fen Bilimleri Enstitüsü, Manisa.

Çiğdemtekin, B. (2007). Fizik ĕgitiminde elektrostatik konusu ile ilgili kavram yanılgılarının giderilmesine yönelik bir karikatüristik yaklaşım. (Yayımlanmış yüksek lisans tezi), Gazi Üniversitesi, Eğitim Bilimleri Enstitüsü, Ankara.

Demir, S., Böyük, U. ve Koç, A. (2011). Fen ve teknoloji dersi öğretmenlerinin laboratuvar şartları ve kullanımına ilişkin görüşleri ile teknolojik yenilikleri izleme eğilimleri. Mersin Üniversitesi Ĕ̆itim Fakültesi Dergisi, 7(2), 66-79.

Demir, Y., Uzoğlu, M. ve Büyükkasap, E. (2012). Fen bilgisi öğretmen adaylarının kuvvet ve hareket ile ilgili sahip olduğu kavram yanılgılarının belirlenmesinde kullanılan karikatürlerin ve çoktan seçmeli soruların etkililiğinin karşılaştırılması. Eğitim ve Öğretim Araştırmaları Dergisi, 1(1), 88-102.

Duban, N. Y. (2013). Sınıf öğretmenlerinin kavram karikatürlerini hazırlama ve kullanmaya yönelik görüşleri. Akademik Araştırmalar Dergisi, 14(56), 35-54.

Durmaz, B. (2007). Yapılandırıcı fen ögretiminde kavram karikatürlerinin öğrencilerin başarısı ve duyuşsal özelliklerine etkisi (Muğla İli Merkez İlçe Örneği). (Yayımlanmış yüksek lisans tezi), Muğla Üniversitesi, Fen Bilimleri Enstitüsü, Muğla. 
Ekici, F., Ekici, E. ve Aydın, F. (2007). Utility of concept cartoons in diagnosing and overcoming misconceptions related to photosynthesis. International Journal of Environmental and Science Education, 2(4), 111 - 124.

Ekici, G. (1996). Biyoloji öğretmenlerinin ögrretiminde kullandıklarl yöntemler ve karşılaştıkları sorunlar. (Yayımlanmamış yüksek lisans tezi), Ankara Üniversitesi, Sosyal Bilimler Enstitüsü, Ankara.

Erdoğan, A. ve Özsevgeç, L. C. (2012). Kavram karikatürlerinin öğrencilerin kavram yanılgılarının giderilmesi üzerindeki etkisi: Sera etkisi ve küresel ısınma örneği. Turkish Journal of Education, 1(2), 1-13.

Eroğlu, N. (2010). 6. sınıf "maddenin tanecikli yapısı" ünitesindeki kavramların öğretiminde ögrenci ürünü karikatürlerin kullanımı. (Yayımlanmış yüksek lisans tezi), Sakarya Üniversitesi, Fen Bilimleri Enstitüsü, Sakarya.

Erten, S. (1991). Biyoloji laboratuvarlarının önemi ve laboratuvarda karşılaşılan güçlükler. (Yayımlanmamış yüksek lisans tezi), Gazi Üniversitesi, Fen Bilimleri Enstitüsü, Ankara.

Evrekli, E. ve Balım, A. G. (2015). Fen derslerinde animasyon destekli kavram karikatürleri kullanımının altıncı sınıf öğrencilerinin sorgulayıcı öğrenme becerileri algılarına etkisi. Batı Anadolu Eğitim Bilimleri Dergisi, 6(11), 109- 136.

Greenwald, S. J. ve Nestler, A. (2004). Engaging students with significant mathematics from the Simpsons. Primus, 14(1), 29-39.

Gül, Ş., Köse, E. Ö. ve Konu, M. (2014). Genetik ünitesinin öğretiminde kavram karikatürü kullanımının biyoloji öğretmeni adayları üzerine etkisi. Fen Bilimleri Öğretimi Dergisi, 2(1), 1-22.

Güneş, M. H., Güneş, O. ve Hoplan, M. (2012). Fen bilgisi öğretmen adaylarının fen bilgisi laboratuvar uygulamaları I-II dersine yönelik görüşleri. Journal of Educational and Instructional Studies in the World, 2(1), 102-109.

Güneş, M. H., Şener, N., Germi-Topal, N. ve Can, N. (2013). Fen ve teknoloji dersinde laboratuvar kullanımına yönelik öğretmen ve öğrenci değerlendirmeleri. Dicle Üniversitesi Ziya Gökalp Ĕ̈itim Fakültesi Dergisi, 20, 1-11. 
İnel, D. ve Balım, A. G. (2011). Kavram karikatürleri destekli probleme dayalı öğrenme yönteminin ilköğretim altıncı sınıf öğrencilerinin fen öğrenmeye yönelik motivasyonlarına etkisi. Uşak Üniversitesi Sosyal Bilimler Dergisi, 4(1), 169-188.

İnel, D., Balım, A. G. ve Evrekli, E. (2009). Fen öğretiminde kavram karikatürü kullanımına ilişkin öğrenci görüşleri. Necatibey Eğitim Fakültesi Elektronik Fen ve Matematik Ĕ̈itimi Dergisi, 3(1), 1-16.

İzgi, Ü. (2012). Öğretmen adaylarının ĕgitiminde ve ilköğretim l. kademe fen ĕgitiminde kavram karikatürü kullanımının etkileri. (Yayımlanmış doktora tezi), Hacettepe Üniversitesi Sosyal Bilimler Enstitüsü, Ankara.

Kabapınar, F. (2005). Effectiveness of teaching via concept cartoons from the point of view of constructivist approach. Kuram ve Uygulamada Eğitim Bilimleri Dergisi, 5(1), 135- 146.

Köklükaya, A. N., Güven- Yıldırım, E. ve Selvi, M. (2016). The effects of cartoons prepared by pre-service science teachers on academic achievement and anxiety level. Eğitimde Kuram ve Uygulama, 12(2), 427-446.

Köse, S., Coştu, B. ve Keser, Ö., F. (2003). Fen konularındaki kavram yanılgılarının belirlenmesi: TGA yöntemi ve örnek etkinlikler. Pamukkale Üniversitesi Ĕgitim Fakültesi Dergisi, 13(13), 43-53.

Meriç, G. (2014). Fen ve teknoloji dersinde kavram karikatürlerinin ögrencilerin kavramsal anlama, motivasyon ve tutum düzeyleri üzerine etkisi. (Yayımlanmış yüksek lisans tezi), Celal Bayar Üniversitesi, Fen Bilimleri Enstitüsü, Manisa.

Meşeci, B., Karamustafaoğlu, S. ve Bacanak, A. (2012, Haziran). Yaratıcı drama yöntemiyle maddenin değişimi konusunun ögrretimi: NVIVO değerlendirme. X. Ulusal Fen Bilimleri ve Matematik Eğitimi Kongresi, Niğde.

Mısır, N. ve Saka, A. Z. (2012, Haziran). Fizik öğretiminde elektriksel iş ve ısı konusunda tahmin et-gözle-açıkla yöntemine dayalı olarak geliştirilen etkinlik uygulaması. X. Ulusal Fen Bilimleri ve Matematik Eğitimi Kongresi, Niğde. 
Miles, M. B., Huberman, A. M., ve Saldana, J. (2014). Qualitative Data Analysis: A Methods Sourcebook. ( $3^{\text {th }}$ Edition). Thousand Oaks, CA: SAGE Publications. https://books.google.com.tr/ adresinden elde edildi.

Minárechová, M. (2016). Using a concept cartoon method to address elementary school students' ideas about natural phenomena. European Journal of Science and Mathematics Education, 4(2), 214-228.

Oluk, S. ve Özalp, I. (2007). The teaching of global environmental problems according to the constructivist approach: As a focal point of the problem and the availability of concept cartoons. Educational Sciences: Theory and Practice, 7(2), 881-896.

Özalp, I. (2006). Karikatür tekniğinin fen ve çevre eğitiminde kullanılabilirliği üzerine bir araştırma. (Yayımlanmış yüksek lisans tezi), Celal Bayar Üniversitesi, Fen Bilimleri Enstitüsü, Manisa.

Özmen, H., Demircioğlu, G., Burhan, Y., Naseriazar, A. ve Demircioğlu, H. (2012). Using laboratory activities enhanced with concept cartoons to support progression in students' understanding of acid-base concepts. Asia-Pacific Forum on Science Learning and Teaching, 13(1), 1-29.

Özüredi, Ö. (2009). Kavram karikatürlerinin ilköğretim 7. sinıffen ve teknoloji dersi, insan ve çevre ünitesinde yer alan "besin zinciri” konusunda öğrenci başarlsı üzerindeki etkisi. (Yayımlanmış yüksek lisans tezi), Celal Bayar Üniversitesi, Fen Bilimleri Enstitüsü, Manisa.

Özyılmaz-Akamca, G., Ellez, A. M. ve Hamurcu, H. (2009). Effects of computer aided concept cartoons on learning outcomes. Procedia Social and Behavioral Sciences, 1(1), 296-301.

Özy1lmaz-Akamca, G., ve Hamurcu, H. (2009). Analojiler, kavram karikatürleri ve tahmingözlem-açıklama teknikleriyle desteklenmiş fen ve teknoloji eğitimi. E-Journal of New World Sciences Academy, 4(4), 1186-1206.

Patton, M. Q. (2014). Nitel araştırma ve değerlendirme yöntemleri. (3. Basım). (Çev. Bütün, M. ve Demir, S. B.). Ankara: Pegema Akademi. 
Rule, A. C. ve Auge, J. (2005). Using humorous cartoons to teach mineral and rock concepts in sixth grade science class. Journal of Geoscience Education, 53(5), 548-558.

Say, F. S. (2011). Kavram karikatürlerinin 7. sınıf öğrencilerinin "maddenin yapısı ve özellikleri” konusunu öğrenmelerine etkisi. (Yayımlanmış yüksek lisans tezi), Karadeniz Teknik Üniversitesi, Eğitim Bilimleri Enstitüsü, Trabzon.

Şaşmaz-Ören, F. (2009). Öğretmen adaylarının kavram karikatürü oluşturma becerilerinin dereceli puanlama anahtarıyla değerlendirilmesi. Education Sciences, 4(3), 994-1016.

Şaşmaz- Ören, F. ve Meriç, G. (2014). Seventh grade students' perceptions of using concept cartoons in science and technology course. International Journal of Education in Mathematics, Science and Technology, 2(2), 116-136.

Şengül, S. ve Üner, İ. (2010). What is the impact of the teaching "Algebraic expressions and equations" topic with concept cartoons on the students' logical thinking abilities? Procedia Social and Behavioral Sciences, 2, 5441-5445.

Taşlidere, E. (2013). The effects of concept cartoon worksheets on students' conceptual understandings of geometrical optics. Eğitim ve Bilim, 38(167), 144-161.

Topkaya, Y. (2016). Doğal çevreye duyarlılık değerinin aktarılmasında kavram karikatürleri ile eğitici çizgi romanların etkililiğinin karşılaştırılması. Mustafa Kemal Üniversitesi Sosyal Bilimler Enstitüsü Dergisi, 13(34), 259-272.

Türnüklü, A. (2000). Eğitimbilim araştırmalarında etkin olarak kullanılabilecek nitel araştırma tekniği: Görüşme. Kuram ve Uygulamada Eğitim Yönetimi Dergisi, 6(4), 543-559.

Uşaklı, H. ve Akpınar, E. (2015). Fen laboratuvarı kaygı ölçeğinin (FLKÖ) geliştirilmesi. Kastamonu Üniversitesi Kastamonu Eğitim Dergisi, 23(3), 1241-1250.

Van Der Mescht, H. (2004). Phenomenology in education: A case study in educational leadership. Indo-Pacific Journal of Phenomenology, 4(1), 1-16.

Yavuz, S. ve Çelik, G. (2013). Sınıf öğretmenliği öğrencilerinin gazlar konusundaki kavram yanılgılarına tahmin et-gözle-açıkla tekniğinin etkisi. Karaelmas Ĕ̆itim Bilimleri Dergisi, 1(1), 1-20. 
Ege Eğitim Dergisi 2017 (18) 2: 738-773

Kavram Karikatürü Destekli Fen Öğretimi Hakkında Öğretmen Adaylarının Görüşleri

Yıldırım, A. ve Şimşek, H. (2016). Sosyal bilimlerde nitel araştırma yöntemleri. (10. Bask1.). Ankara: Seçkin Yayınları.

Y1ldız, İ. (2008). Kavram karikatürlerinin kavram yanılgllarının tespitinde ve giderilmesinde kullanılması: düzgün dairesel hareket. (Yayımlanmış yüksek lisans tezi), Gazi Üniversitesi, Eğitim Bilimleri Enstitüsü, Ankara. 


\section{Extended Abstract}

The innovation of science education started in 1960s in western countries has affected the Turkish National Education and student-centered applications and laboratory studies were included into the curriculum of the science education in our country. As the science education depends on the experiment, observation, discovery, research, and discussion; the importance of the laboratory management is important. However, it is necessary to improve the physical opportunities (equipment, materials etc.) and the skills of the teachers using these facilities should be adequate for using the laboratory management effectively. In such a case, studies about the laboratory applications for the science prospective teachers at education faculties gain importance. In this study regarding to the purpose, science course laboratory applications were carried out by using POE (Prediction-Observation-Explanation) method as a sample application to the third grade science prospective teachers. In this teaching method, the activities supported by concept cartoons were used. At prediction level, concept cartoons developed for biology subjects; at observation level, experiments with groups or individual and at the explanation level knowledge given by the researchers were used.

POE is a laboratory method that provides different teaching methods in itself. In this study, it is aimed to describe the teaching and learning activities of the prospective teachers in POE teaching method. Furthermore, it is thought that different teaching activities and methods make the learning easier for the prospective teachers.

Although there are many researches on concept cartoon in literature, the number of qualitative studies are limited in science education about using concept cartoons (Aydin, 2015; Cengizhan, 2011; Duban, 2013; İnel, Balım \& Everekli, 2009; Şaşmaz-Ören \& Meriç, 2014). In the present study, it was aimed to provide a basis to the qualitative studies in science education and to get the opinions of the science prospective teachers about the laboratory application in science teaching supported by concept cartoons.

The present study was carried out by using phenomenological method which is one of the qualitative methods. The sample of the study contained prospective teachers $(n=6)$ attending to the third grade of the science department. While determining the sample of the research, scale sampling method was used. The data in the study were obtained through semistructured interviews of nine questions prepared by the researchers. NVIVO 9.0 program was used to analyze the obtained data. 
According to the obtained data, science prospective teachers had some anxieties about using the concept cartoons before the teaching session but it was seen that their anxieties disappeared after the class. When the effect of the concept cartoons on the learning was examined, prospective teachers claimed that using such an activity made the learning steady and the students could improve their psycho-motor development. Most of the prospective teachers expressed that if the concept cartoons were supposed to be effective, they should be colorful or given in the form of animation.

The prospective teachers said that they were anxious about teaching science with concept cartoon before the lesson. However, their anxieties became less after using them in their teaching. They also claimed that teaching science with concept cartoon helped students keep the topic in mind and misconceptions about the topic disappeared after the lesson. With the help of this activity, the prospective teachers said that they had experience and they would use it when they start their teaching careers. Science education with concept cartoon support made the laboratory activities more effective and they expressed that they would present such concept cartoons colorful and in the form of animation. Related to the results of the study, at education faculties, different activities by using special teaching methods in science laboratory applications lesson can be given to the prospective teachers. At each age level and grade, concept cartoons can be used to reduce the worries and to improve positive attitudes towards science. In researches about concept cartoons, the effect of concept cartoons to the attitudes and worries towards the science lesson can be figured out. 
Ege Eğitim Dergisi 2017 (18) 2: 738-773

Kavram Karikatürü Destekli Fen Öğretimi Hakkında Öğretmen Adaylarının Görüşleri

\section{Ekler}

\section{Ek 1. Göz Konusu ile İlgili Öğretmen Adaylarına Verilen Çalışma Kâğıdı}

\section{DUYU ORGANLARIMIZ}

\section{Arastırma Soruları:}

\section{Gözden Fotoğraf Makinesine: Görmenin Teknolojisi}

Bilim adamları gözden ilham alınarak fotoğraf makinesi, kamera, mikroskop, teleskop vb. gibi pek çok teknolojik araç geliştirmişlerdir. Bu teknolojik araçlardan birisi olan fotoğraf makinesi için Phil Gates Wild Technology adlı kitabında, fotoğraf makinelerinin gözü taklit eden basit bir model olduğunu şöyle açıklar:

"Fotoğraf makineleri, omurgalı gözlerinin ilkel ve mekanik bir versiyonudur. Bu makineler aslında aynen göz gibi, önlerindeki açıklık dışında içine ışık geçirmeyen kutulardır. Görüntüyü retina yerine bir film üzerine yansıttrlar. Gözlerde görüntüye odaklanma merceğin şekli değiştirilerek olur. Fotoğraf makinelerinde ise bu işlem merceğin filme olan mesafesi değiştirilerek gerçekleştirilir."

* İnsan gözü ile fotoğraf makinesinde olușan görüntü arasındaki farklar nelerdir? Açıklayınız.

\section{TAHMIN ASAMASI}

Ali dart oyunu oynarken tek gözünü kapatarak nişan aldığında hedefi daha kolay vurabiliyor. Ancak Ali tek gözünü kapatarak iğneyi ipin deliğine geçirmeyi denediğinde başarılı olamıyor.

Nasıl oluyor da tek gözü kapalı iken hedefi nişan alıp vurabiliyorken iğnenin deliğini nişan alıp ipi geçiremiyor? Bu durumu anlaması için haydi ona yardımcı olalım.
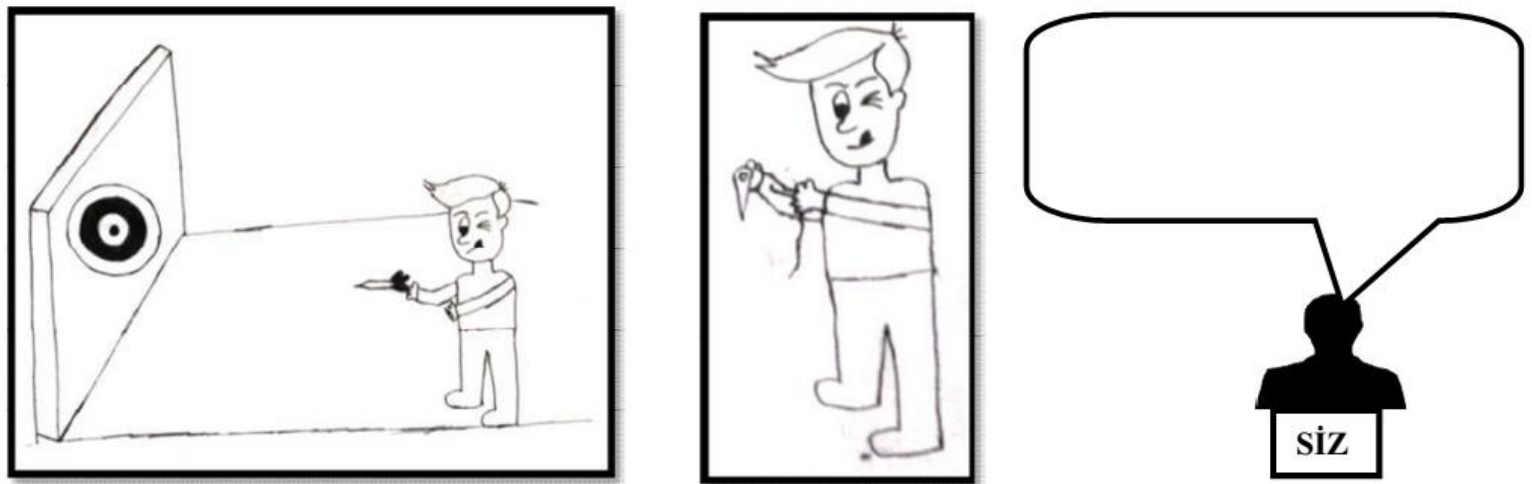

Bence Ali'nin dart oyununda tek gözünü kapatarak nișan aldığında daha başarılı olmasının nedeni hedef tahtasının uzakta olmasıdır. Uzakta olan cisimleri tek gözümüzle daha kolay vurabiliriz.

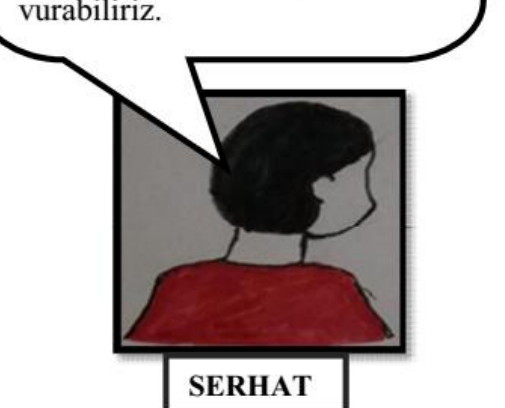

Hayır, sana katılmıyorum Serhat. Bence Ali'nin ipi iğnenin deliğine geçirememesinin nedeni uzağ daha iyi görüp yakını görememesidir. Yani Ali hipermetrop olabilir. 
Karikatürleri inceleyiniz.

Sizce hangi öğrenci doğru cevabı vermektedir? Bu düşüncenizin nedenini açıklayınız.(Eğer bu öğrencilere katılmıyorsanız siz karakterinin balonuna kendi düşüncenizi gerekçesiyle birlikte yazınız.)

.

.

\section{GÖZLEM ASAMAS}

Kullanılacak Araç Gereçler: İnce uçlu ispirtolu kalem, cetvel, zımba deliğinden çıkmış yuvarlak kâğıt parçaları

Deneyin Amacı: Deneğin duraklamadan, kalemin ucu ile kâğıt parçasına dokunabilmesidir.

\section{Deneyin Yapılıșı:}

1. Bir arkadaşınızla birlikte çalışınız. Bir kişi deneyin yöneticisi, diğer kişi denek olarak görev yapacaktır.

2. Denek, masanın yüzeyi ile gözleri aynı hizada olacak şekilde diz çökecektir. (aşağıdaki şekle bakınız.)

3. Denek bir gözünü kapatarak, deney yöneticisinin yaklaşık $30 \mathrm{~cm}$ yükseklikten masanın üzerine bıraktığı kâğıda duraklamadan dokunmaya çalışacaktır.

4. Hedef ( kâğıt parçası) ile deneğin kalem ile dokunduğu yer arası uzaklığı ölçünüz. Sonucu aşağıdaki tabloya not ediniz. Tam isabet " $0 \mathrm{~cm}$ " olarak yazılacaktır.

5. Deneyi 5 kez tekrarlayınız. Tek gözle ortalama hedefi şaşırma oranını hesaplayınız.

6. Deneyi $5 \mathrm{kez}$ daha, fakat bu sefer iki göz de açık şekilde yapınız. Elde ettiğiniz veriler tabloya yazınız ve ortalama hedefi şaşırma oranını hesaplayınız.

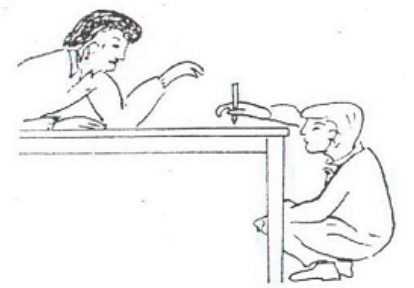

Veriler:

\begin{tabular}{|l|l|l|}
\cline { 2 - 3 } \multicolumn{1}{c|}{} & \multicolumn{2}{c|}{ Hedefi şaşırma oranı (mm cinsinden) } \\
\hline Deney & Tek göz açık & Her iki gözde açık \\
\hline 1 & & \\
\hline 2 & & \\
\hline 3 & & \\
\hline 4 & & \\
\hline 5 & & \\
\hline Ortalama & & \\
\hline
\end{tabular}

\section{Deneyin Sonucu:}




\section{ACIKLAMA ASAMASI}
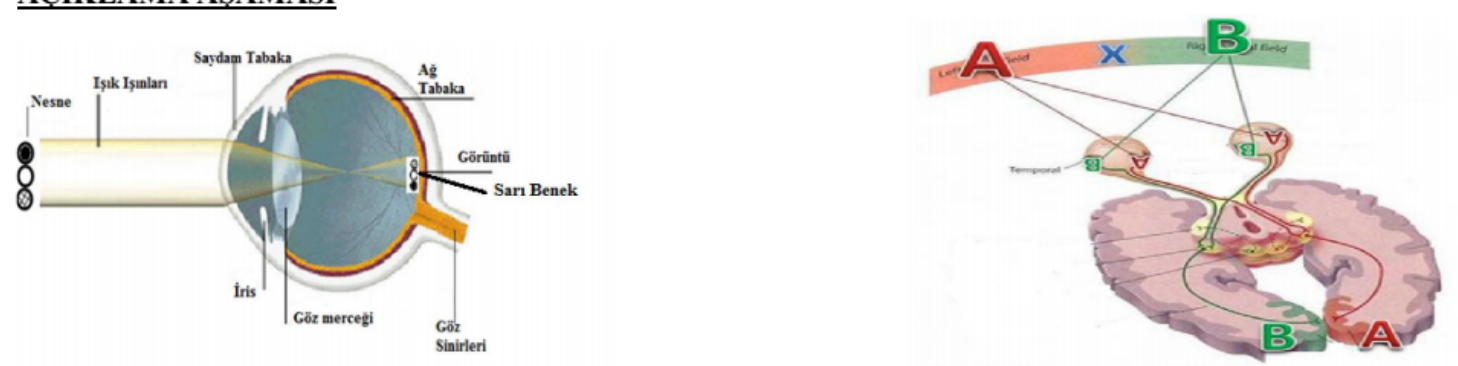

Yukarıdaki şekillerde görüldüğü gibi gözde görüntü oluşurken cisimden yansıyan ışınlar sırasıyla şu yapılardan geçmektedir:

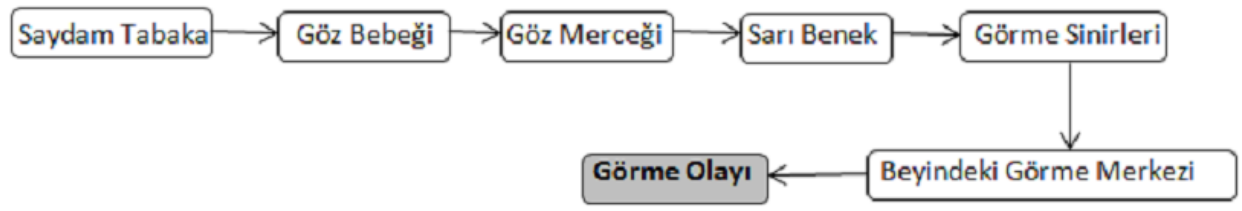

Her bir gözde ayrı ayrı ayrı oluşan bu ters görüntüler beyindeki görme merkezinde birleştirilip, düzeltilir. Böylece görme olayı gerçekleșmiş olur. Her bir gözde ayrı ayrı oluşan görüntüler fotoğraf gibi iki boyutludur. Ancak biz üç boyutlu görürüz. Bu olay her bir gözümüzde oluşan iki görüntünün beyinde birbiriyle karşılaştırılmasıyla gerçekleşir. Beynimiz iki ayrı görüntüyü birleştirirken aynı zamanda karşılaş̦tırmada yapar. Bu karşıllaştırma sayesinde cisimlere baktığımız derinlik algımız oluşur. Böylece etrafımızı fotoğraf gibi iki boyutlu olarak değil üç boyutlu olarak görmüş oluruz. Yukarıdaki karikatürde bahsedilen iki olay arasında boyut farkı vardır. Birinci olayda Ali hedef tahtasına nişan alırken hedef tahtası, Ali'nin atacağı dart iğnesi ve Ali’nin gözü aynı optik düzlem üzerinde yer almaktadır. Bu nedenle olay tek boyutludur. Dolayısıyla nişan alırken tek gözümüzü kullanarak hedefi vurabiliriz. Ancak Ali ipi iğnenin deliğine geçirmeye çalışırken Ali’nin gözü, ip ve iğne aynı düzlem üzerinde değildir. Alinin bu işi kolaylıkla yapabilmesi ip ile iğne arasındaki derinliği algılaması gerekir. Bu nedenle iki gözü ile bakmalıdır.

\section{Değerlendirme}

1. Deneyin sonucuna dayanarak tek gözle ile görmenin ortaya çıkaracağı engellere örnek veriniz.

2. İnsan gözü gibi üç boyutlu bir fotoğraf çekimi yapabilen bir fotoğraf makinası tasarlasaydınız nasıl tasarlardını. 
Ek 2. Alt Problemlere Yöneltilen Yarı Yapılandırılmış Mülakat Soruları

1. Fen bilgisi öğretmen adaylarının genel olarak kavram karikatürü destekli olarak yürütülen fen öğretimi laboratuvarı dersi hakkındaki düşünceleri nelerdir?

1.1. Üniversitede öğreniminiz sürecinde kavram karikatürleriyle desteklenmiş dersleriniz oldu mu? Açıklar mısınız?

1.2. Fen öğretimi laboratuvarı dersinin kavram karikatürleriyle yürütüleceğini ve derste nasıl uygulanacağını öğrendiğinizde ilk düşünceleriniz ne oldu? Açıklar mısınız?

1.3. Fen öğretimi laboratuvarı dersinde karikatürlerle öğretim yapıldıktan sonra ilk düşüncelerinizde herhangi bir değişiklik oldu mu? Açıklayınız.

1.4. Karikatürle desteklenmiş fen öğretimi laboratuvarı dersi hakkında şu anda neler düşünüyorsunuz? Açıklayınız.

2. Fen bilgisi öğretmen adaylarının kavram karikatürlü destekli fen öğretimi laboratuvarının kendi öğrenmeleri üzerindeki düşünceleri nelerdir?

2.1. Kavram karikatüründe yararlanılan dersinizi diğer öğretim yöntemleriyle yürütülen derslerden ayıran en önemli yerleri nelerdir? Açıklayınız.

2.2. Fen öğretimi laboratuvarı dersinde karikatürlerden yararlanılması öğretmen adaylarına neler kazandırır? Sebebini açıklar mısınız?

2.3. Kavram karikatürlerinin öğretimde kullanılmasının öğrenmeye ne gibi katkıları olabilir? Açıklar mısınız?

3. Fen bilgisi öğretmen adaylarının kavram karikatürü destekli fen öğretimi laboratuvarının etkili olabilmesi konusundaki düşünceleri nelerdir?

3.1. Karikatürler fen öğretimi laboratuvarı dersinin hangi bölümünde kullanılmalıdır? Açıklar mısınız?

3.2. Fen öğretimi laboratuvarı dersinde karikatürlerle yapılan öğretimin etkili olabilmesi için neler yapılmalıdır? Açıklayınız. 